The undersigned hereby recommend to the Faculty of Graduate Studies and

Research acceptance of the thesis

\title{
Customer Values of Communication Enabled Application Mashup Types
}

\author{
submitted by \\ Howard Rosenblum \\ In partial fulfillment to the requirements for the degree of Master of Applied
}

Science in Technology Innovation Management

Howard Schwartz, Department Chair

A.J. Bailetti, Thesis Supervisor

Carleton University

November 2011 
Library and Archives

Canada

Published Heritage

Branch

395 Wellington Street

Ottawa ON K1A ON4

Canada
Bibliothèque et

Archives Canada

Direction du

Patrimoine de l'édition

395 , rue Wellington

Ottawa ON K1A ON4

Canada
Your file Votre référence

ISBN: 978-0-494-87805-7

Our file Notre référence

ISBN: $978-0-494-87805-7$

\section{NOTICE:}

The author has granted a nonexclusive license allowing Library and Archives Canada to reproduce, publish, archive, preserve, conserve, communicate to the public by telecommunication or on the Internet, loan, distrbute and sell theses worldwide, for commercial or noncommercial purposes, in microform, paper, electronic and/or any other formats.

The author retains copyright ownership and moral rights in this thesis. Neither the thesis nor substantial extracts from it may be printed or otherwise reproduced without the author's permission.
AVIS:

L'auteur a accordé une licence non exclusive permettant à la Bibliothèque et Archives Canada de reproduire, publier, archiver, sauvegarder, conserver, transmettre au public par télécommunication ou par l'Internet, prêter, distribuer et vendre des thèses partout dans le monde, à des fins commerciales ou autres, sur support microforme, papier, électronique et/ou autres formats.

L'auteur conserve la propriété du droit d'auteur et des droits moraux qui protege cette thèse. $\mathrm{Ni}$ la thèse ni des extraits substantiels de celle-ci ne doivent être imprimés ou autrement reproduits sans son autorisation.
In compliance with the Canadian Privacy Act some supporting forms may have been removed from this thesis.

While these forms may be included in the document page count, their removal does not represent any loss of content from the thesis.
Conformément à la loi canadienne sur la protection de la vie privée, quelques formulaires secondaires ont été enlevés de cette thèse.

Bien que ces formulaires aient inclus dans la pagination, il n'y aura aucun contenu manquant. 


\section{ABSTRACT}

This exploratory research examines mashups that combine Information Technology and Communication Application Programming Interfaces(APIs) in the "ProgrammableWeb" website and data from websites of mashup suppliers to (i) organize mashups into mashup types(mashups that combine similar APIs), (ii) define the suppliers' description of customer value of these mashup types and (iii) provide insights about communications enabled applications. Results suggest that while many mashup types exists only a small number of mashups exist per type; Current CEA mashups are the convergence of Information Technology applications with Communication features but do not create a new application type; messaging is the most common enhancement; and suppliers of these applications are having difficulty defining the customer value they provide. 


\section{ACKNOWLEDGMENTS}

I would like to thank my supervisor, Prof. Tony Bailetti, for his support through the thesis development process. I would also like to thank the women in my life, my wife Michelle, for her encouragement to start, support to complete, and countless edits during the entire graduate process and daughters Beatrice and Lillian for being the reason I wanted to be a better person. 


\section{Table of Contents}

Table of Contents .......................................................................................

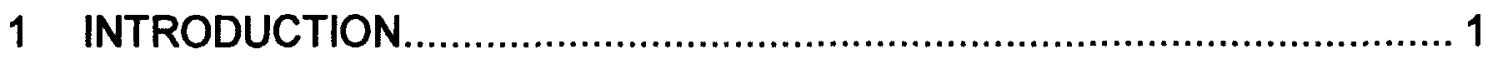

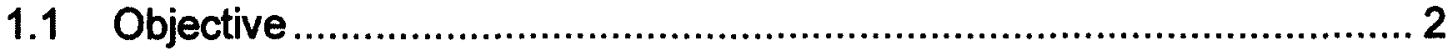

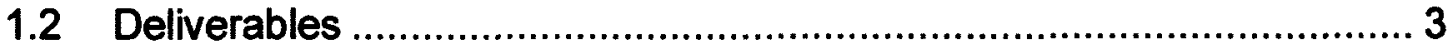

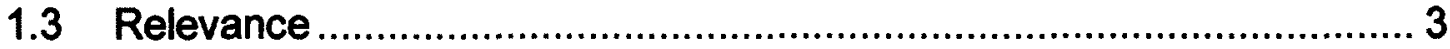

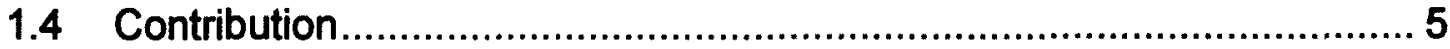

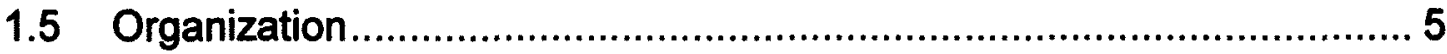

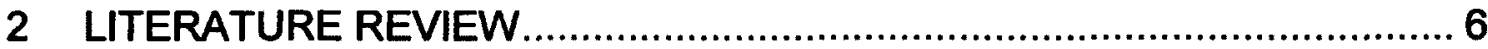



2.2 Communication Enabled Applications …………………………........... 12

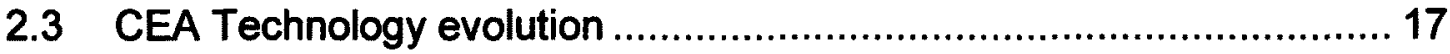

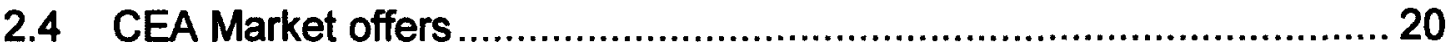

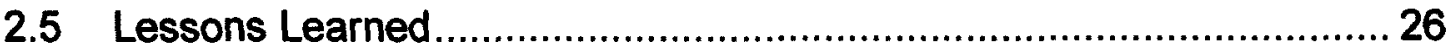

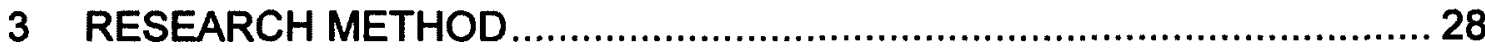

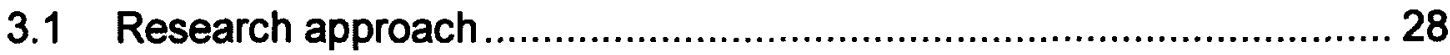



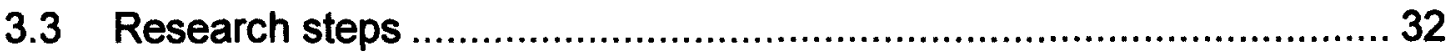

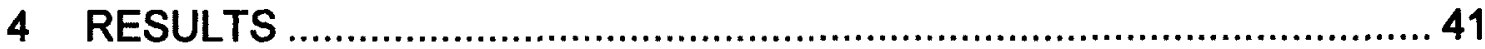

4.1 Classification Development .............................................................. 41

4.2 CEA Mashup Type Identification ....................................................... 48

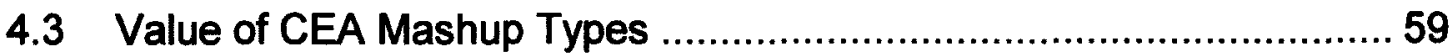

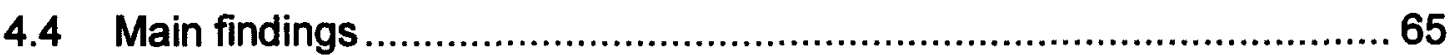

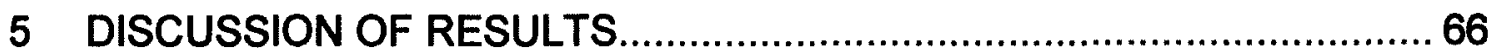

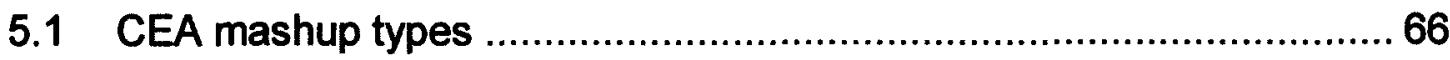

5.2 CEA mashup customer values ........................................................ 70

5.3 Linkage between research findings and literature review ..................... 80

6 CONCLUSIONS, LIMITATION, AND FUTURE RESEARCH ...................... 84



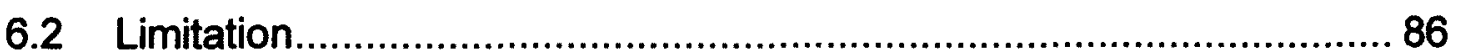

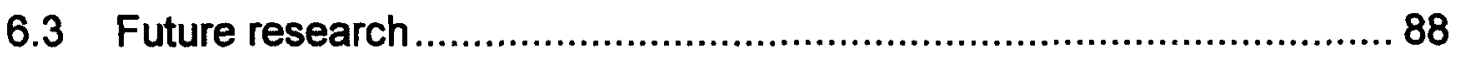




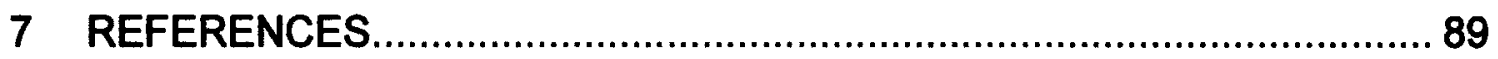




\section{List of Tables}



Table 2 - CEA mashups based on communication and IT categories ............. 37

Table 3 - CEA mashup types based on communication and IT categories.......38

Table 4 - CEAs based on mashup type and supplier stated values................. 40

Table 5 - Classification of API categories in the ProgrammableWeb.............. 45

Table 6 - ProgrammableWeb final category classification ..............................4 47

Table 7 - Automated CEA mashup initial results ........................................5 50





Table 10 - General Inquirer Lasswell tag categories and definitions ..............61 61

Table 11 - CEA Mashup type value percentages ..........................................63 63

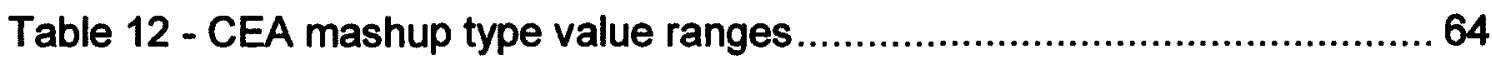

Table 13 - CEA mashup types by number of mashups that they contain ........ 67

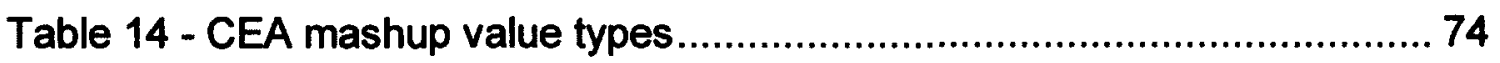

Table 15 - CEA Mashup type domain value percentages ............................. 75 


\section{List of Figures}

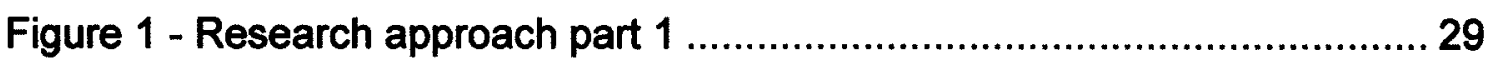

Figure 2 - CEA Mashup type domain graph ............................................. 76

Figure 3 - CEA Mashup types by Communication APIs graph ...................... 78

Figure 4 - CEA Mashup types by IT APIs graph........................................ 79 


\section{INTRODUCTION}

Communications enabled applications (CEAs) have been identified as an area of growth for Ottawa (Haw 2009) but could equally be seen as a growth area for the larger technology field. CEAs are loosely defined as software applications that have both an information technology (IT) and a communication component.

The motivation for this research is to identify CEA mashup types (mashups that combine similar APIs). CEAs will be organized into types based on IT and communication components used in a mashup as well as suppliers' descriptions of the value their CEAs deliver customers.

For the purpose of this research, communication enablement, market offer, customer value and mashup mean the following:

- Communication enablement refers to: (i) IT applications that have a communication component (e.g., webpage that has the functionality for a potential customer to initiate a phone conversation with another person); and (ii) Communication applications that have IT components (e.g., a mobile phone application that provides restaurant recommendations based on current location) 
- Market offer (offer) is: i) the product or service purchased; ii) how the purchase is done; and iii) the rights the supplier grants to the purchaser. (Bailetti 2009)

- Customer value is the points of difference of a market offer that matter the most to the target customer, "demonstrating and documenting the value of this superior performance, and communicating it in a way that conveys a sophisticated understanding of the customer's business priorities" (Anderson, Narus \& Van Rossum 2006).

- A mashup is an application that combines content from more than one source into an integrated experience (Banerjee \& Dasgupta 2008). Communications enabled application (CEA) mashups can be considered to be a subclass of mashups since they combine Communication Application Programming Interfaces (APIs) with IT APIs.

\subsection{Objective}

The objective of this research is to define the CEA mashup value types by examining suppliers' offers.

The questions to be addressed are: 
- What values do CEA mashups provide to their customers?

- What are the types of CEA mashups that exist?

- What values do each of the CEA mashup types provide to their customers?

\subsection{Deliverables}

The deliverables of this research are:

- Identification of CEA mashup types based on mashup APIs

- Identification of CEA mashup types based on their suppliers' statements of customer value

- Insights on communications enabled applications

\subsection{Relevance}

This research is relevant to at least four groups: entrepreneurs, owners of existing businesses, academics, and economic development organizations.

This research is relevant to entrepreneurs because it provides a benchmark of the value that CEA suppliers offer their customers and provides insights on the 
current state of CEA technology. For example, entrepreneurs will be able to find potential opportunities examining CEA types that have no mashups.

This research is relevant to owners of existing businesses because it suggests ways to improve the company's market offer. Given their current products and services, what values could they provide or enhance? For example, can a business use communication technology to improve the experience with their customers.

This research is relevant to academics because it introduces communications enablement as a new area of research. Some of the follow-on topics could be: How do the customer and supplier perspectives of communication enabled applications differ? What communication enablements provide suppliers with a competitive advantage?

This research is relevant to economic development organizations because it provides an area to create a technology hot bed. This research was part of a start of the development of such a technology hot bed. 


\subsection{Contribution}

This research:

- Views CEAs in terms of their value to customers, as opposed to combinations among synchronous and asynchronous components

- Provides a common language for managers to talk about sources of value that can be expected to be derived from CEAs

- Sets benchmarks for expectations of customer value derived from CEAs

\subsection{Organization}

This thesis is organized into six chapters. The first chapter provides an introduction. Chapter 2 reviews four literature streams: (i) Mashups, (ii) CEAs, (iii) CEA technology evolution, and (iv) CEA market offers. Chapter 3 describes the research method used. Chapter 4 provides the results of customer value provided by CEAs. Chapter 5 is an analysis of the results. Chapter 6 provides the conclusions, research limitations and suggestions for future research. 


\section{LITERATURE REVIEW}

Chapter $\mathbf{2}$ is organized into five sections. The first four sections review the following literature streams: mashups (Section 2.1), CEAs (Section 2.2), CEA technology evolution (Section 2.3) and CEA market offers (Section 2.4). Finally section 2.5 provides the lessons learned from the literature review.

\subsection{Mashups}

Mashups allow the mixing of data, presentation and functionality from multiple sources for uses beyond the original intent. The most popular purpose is the visualization of numerical data to detect patterns that could not otherwise be observed. For example, the "Your Mapper" mashup (http://www.yourmapper.com/) presents on a map diverse data as attractions, public health and safety, and other statistics.

The "Your Mapper" mashup is an example of a consumer mashup that provides services to the public. There are also data and enterprise mashups. Data mashups combine data from multiple external sources into a single presentation. Enterprise mashups combine data from internal sources for corporate use, using such tools as JackBe (www.jackbe.com), and Kapow Technologies (www.kapowtech.com) (Gamble \& Gamble 2008). 
Breemer and Gregg (2009) organized mashup research into six themes: (i) Access control and cross communications, (ii) Mashup integration, (iii) Mashup agents, (iv) Mashup frameworks, (v) End user programming, and (vi) Enterprise mashups. In the course of doing the literature review for this research, a number of mashup articles were found that did not fit any of the above six themes. This paper adds a seventh theme, Mashup evolution, which describes such mashup articles.

By definition, mashups connect data from various sources (Banerjee \& Dasgupta 2008). The access control issue arises because a mashup must deal with different sources that may have different security requirements. For example, the U.S. government concurrently needs to (i) provide information to the public to satisfy the "Freedom of Information Act", (ii) protect individual information to satisfy the "Privacy Act" (Warner \& Chun 2009), and (iii) deal with the limitations of the present web browser security model (Crites, Hsu \& Chen 2008). There are also communication issues that must ensure that a data source does not have undesirable interactions with other sources (Barth, Jackson \& Mitchell 2009; Magazinius, Askarov \& Sabelfeld 2010) or the client (Chong, Liu, Myers, Qi, Vikram, Zheng \& Zheng 2009).

Unlike the web service composition of business (process) services only, mashups must integrate heterogeneous data sources, and are typically specified 
and deployed very rapidly (Abiteboul, Greenshpan \& Milo 2008; Lorenzo, Hacid, Paik \& Benatallah 2009). Integration occurs at the data, process, and presentation levels (Lorenzo, Hacid, Paik \& Benatallah 2009). The data level is responsible for the conversion, filtering, format transformation, combination of data retrieved from various data sources. The process level is for combining applications, generally exposed through APIs using either programming languages such as Java or dedicated workflow languages. The presentation level combines Hypertext Markup Language (HTML), JavaScript, and Extensible Markup Language (XML), (Murthy, Maier \& Delcambre 2006). Recent research (Cappiello, Daniel, Matera \& Pautasso 2010) has determined that components (i.e., data, processes, and presentations) can serve different roles in a mashups. The component roles are Master (the main component in the mashup), Slave (a supporting component), and Filter (component to reduce data shown by other components). Integrations fall into three patterns: Slave-slave, Master-slave, and Master-master. The quality of the integrations must be measured in terms of their accuracy, completeness, timeliness, availability and consistency. Other patterns that have been identified are the Pipes and Filters pattern (sequential components), Data Federation pattern (parallel components) and Model-ViewController pattern (formalization of the interaction of data, presentation, and process) (Liu, Liang, Xu, Staples \& Zhu 2011). 
It is well recognized that mashups will need to process a vast amount of unstructured data (e.g., Benjamins 2008; Rosenberg, Curbera, Duftler \& Khalaf 2008). To add meaning to the unstructured data, authors are using "agents" to create a "semantic web" by the use of machine learning (Tuchinda, Szekely \& Knoblock 2008; Toomim, Drucker, Dontcheva, Rahimi, Thomson \& Landay 2009; Hey 2010), Bayesian networks (Allemang 2006; Zhang, Zhu, Wang \& Zhang 2008), and natural language processing (Murthy, Maier \& Delcambre 2006; Sheth \& Perry 2008; Benjamins 2008). Other agents that have been described are manager agent (to protect the privacy preferences for its host), obfuscation agent (to hide real users' preferences), and synchronize agent (to perform distributed join process) (Elmisery \& Botvich 2011).

Due to the difficulties integrating varied data sources, a number of frameworks have been created to simplify the task for the developers. Some of the frameworks are MashupOS (Wang, Howell \& Jackson 2007), OMash (Crites, Hsu \& Chen 2008), SMash (Keukelaere, Bhola, Steiner, Chari \& Yoshihama 2008), OpenMashupOS (Zarandioon, Yao \& Ganapathy 2008), and "AT\&T speech mashup architecture"(Di Fabbrizio, Okken \& Wilpon 2009). MashupOS is an abstraction framework for secure client-side Web mashups. OMash is a more advanced "abstraction that treats web pages as objects and allows objects to communicate only via their declared public interfaces". SMash is an approach that uses message-passing between trust domains where security policies can 
be specified. OpenMashupOS is "an open-source browser-independent framework for secure inter-domain communication and mashup development". The "AT\&T speech mashup architecture" is a mashup approach to combine web content and speech processing.

Mashups promises to enable non-programmers to create ad-hoc applications using existing data sources (Balasubramaniam, Lewis, Simanta \& Smith 2008; Yu, Benatallah, Casati \& Daniel 2008). Several general purpose tools have been created that do not require the end user to write code, such as Microsoft Popfly, and Yahoo Pipes.

None of the tools make it possible to: combine all web data source types, have a complete set of operators for data integration and manipulation, create mashups without programming experience, or are easy to use (Tuchinda, Szekely \& Knoblock 2008; Yu, Benatallah, Casati \& Daniel 2008; Lorenzo, Hacid, Paik \& Benatallah 2009).

Other tools have been created to solve specific problems, such as Bite (a workflow language that allows integration of Web services, human interaction, collaboration services, and backend services) (Rosenberg, Curbera, Duftler \& Khalaf 2008) and Next Generation Search (an end-user tool to produce an RSS 
feed from the joined results of multiple search engines) (Braga, Ceri, Daniel \& Martinenghi 2008).

Consumer end-users create ad-hoc mashups from sources that are free and freely available. These end-users accept the terms and conditions of the data sources and are responsible for the creation and results of their mashups. In the case of enterprises, the data they need may only be available in legacy systems and they need to assess the technical, quality, contextual, and functional fitness of its use in a mashup (Gamble \& Gamble 2008). Enterprises also need mashups to be architected for long term use (Liu, Liang, Xu, Staples \& Zhu 2011). If enterprises are paying for the mashups and data sources, or the enterprise makes money from the mashup results, then the enterprise requires accountability to identify "all the parties involved and traceability in service composition" (Zou \& Pavlovski 2007), security, quality and availability (Hoyer \& Fischer 2008).

In addition to the research described above, research is being carried out on the growth and structure of existing mashups in the ProgrammableWeb. Some of the findings are:

- APIs are organized into tiers, the distribution of mashups to API form a relatively short power law relationship (Yu \& Woodard 2009). 
- The more often an API has been used in a mashup, the more likely it will be used in future mashups (Hwang, Altmann \& Kim 2009).

- The tendency of APIs to be used in mashups together is related to their position in the ecosystem (Weiss \& Gangadharan 2010).

- New API entrants increase their adoption rate for mashups if they are compatible with the APIs and strategies of the key players (Bardawil 2011).

- Adoption is increased by offering services to developers (Shiga 2011).

\subsection{Communication Enabled Applications}

Using computer technology to enhance telecommunications functionality is not a new idea. The origins can be traced back to Computer Telephony Integrations (CTI) in the 1970s where mainframe computers were used to control private branch exchanges (PBXs), a telephone network within a company. CTI evolved in the 1990s using personal computer technology to provide call control (e.g., automatic dialing and phone call routing), media processing (e.g., voice mail and text-to-speech synthesis), and customer data management capabilities (e.g., use caller id to retrieve customer records). 
Typically, CTI components provide applications such as:

- Interactive Voice Response (IVR), using a telephone to access data from a database

- Screen Pop, a feature that allows an agent (telephone operator) to automatically have the client record on their display when they receive a phone call

- Unified Messaging System (UMS), integration of email, voice mail, and fax in a unified mailbox

- Call Center, a CTI application with IVR, automatic call distribution, and screen pop components (Chou \& Lin 2000).

In well established markets with known technology, the toolkits for constructing $\mathrm{CTI}$ applications from the components are targeted at the end users. It has been shown that it is easier (and more profitable) for end users to learn how to create applications than for toolkit specialists to gain the required domain knowledge (Von Hippel 1998). A study of the computer telephony integration industry found that the importance of customer input increases with market newness of a product up to a point and then drops off for very new products. However, the importance of customer input increases with technological newness of a product without dropping off (Callahan \& Lasry 2004).

Unified Communications (UC) takes the functionality of CTI and combines it with instant messaging (IM), video, multimedia conferencing and application sharing, and the concept of presence (Rybczynski \& Shetty 2005). It is widely touted that the greatest benefit of UC is helping enterprises to raise productivity; and reduce 
travel, telecom and IT operating costs. For example, Cisco's air travel went down almost 40 percent in absolute terms between 2006 and 2009, while Cisco's revenue grew by 27 percent during the same period. Cisco estimated that 50 to 60 percent of the travel reduction was due to telepresence and the remainder to the company's other conferencing products (Sinnett 2010). Beyond the economic factors, UC makes good business sense. "Global enterprises can't function today unless they effectively connect employees, partners, suppliers and customers," says Roberta Mackintosh, the director of Global Unified Communications \& Collaboration Product Marketing for Verizon Business Inc. In addition to Cisco, many other companies are offering UC solutions such as Siemens, AlcatelLucent, Nortel, Avaya, and Mitel. Competition and government regulation drives telecommunications service providers to move 'up the stack' into adjacent market spaces in the IT value chain and offer UC services (Murphy \& Samir 2009; Wu \& Leung 2008). The growth of UC is expected to continue at a rate of $35.9 \%$ through 2015 (Leong 2009).

CEA is the evolution of Unified Communications for the integration and simplification of business applications (Carbone 2008). While UC improves communication between people, CEA will improve productivity in enterprises by reducing human delay in business processes (Roese 2007). The creation of CEAs will provide business applications with a wide range of network communications capabilities such as contact center systems, interactive voice 
response, unified messaging, and unified communications. CEAs will ensure that the right information is sent to the right person. For example, in an emergency situation, an application could send a message (audio, video, text ...) to the closest person (their cell phone, computer ...) that is available to respond.

Computer telephony integration is still well suited for applications that rely on long-running sessions with significant asynchronous events (Becchina, Ciccarelli, Giotis \& Kenny 2007). CTI interfaces are proprietary and tightly coupled to complex telephony switches, making integration a task that is only suited for a relatively small number of expert programmers with a deep knowledge of telephony (Venkatachalam, Dhara, Krishnaswamy \& Vernick 2008). CEA provides an interface based on Service Oriented Architecture (SOA). SOA component functions and services are loosely coupled, thus eliminating the need for specialized telephony knowledge. SOA enables applications to be built and deployed rapidly using reusable components to create enterprise workflows that connect people and business processes (Becchina, Ciccarelli, Giotis \& Kenny 2007).

CEA is much more than just using SOA to deploy UC over the Internet (Kanaparti 2008). In addition to the ease of application construction, CEAs provide new functionality that was not readily available previously. Context awareness allows functionality to be dependent on the situation, such as location (e.g., route desk 
calls to cell phone when out of the office), activity (e.g., convert email to audio message while driving), and time (e.g., send text message to email at night). Autonomics is used to ensure high availability (e.g., if a primary server fails, automatically reroute requests to backup server, and inform authorities of situation), high quality of experience (e.g., automatically optimize resources based on demand), and high security (e.g., automatically detect threats and take corrective action). All of this new functionality is based on user preferences, but requires no extra effort on the part of the user (Carbone \& Romagnino 2007).

Almost any IT applications can be communication enabled including a Customer Relationship Management (CRM) system (Zhang 2009), spreadsheets (Roese 2007; Oberg 2009), virtual organizations (Spencer \& Liu 2008) and business processes (Rake, Holschke, Offermann \& Bub 2009).

An alternate name for communication enabling an IT application is "application enablement". The September 2011 issue of Bell Labs Technical Journal was focused on Application Enablement. The two broad communication service categories described, in this journal issue, as being made available to application developers are: improvement of the delivery and distribution of application traffic (e.g., quality of service guarantees), and providing network-based information/services (e.g. secure payment through mobile account). The specific 
areas of growth are location services; content delivery and transport services; and authentication, payment, and personalization (Kocan \& Robinson 2011).

\subsection{CEA Technology evolution}

The evolution of communication enabled applications, like all technologies, usually follows a very well recognized cyclical pattern. A dominant design emerges to solve a problem or set of problems. The dominant design goes through slow but steady refinements. An innovation that dramatically changes an industry's price vs. performance (technological discontinuity) occurs. There is a period of experimentation and new designs (fermentation) to use the new innovation. Then a dominant design emerges (Anderson \& Tushman 1990).

During the periods of incremental improvements, there are modifications of the basic design, the standards are elaborated, and the technological regime becomes more orderly (Anderson \& Tushman 1990).

The discontinuity may have a lower cost and performance but has additional benefits. The discontinuity will enter and expand emerging market niches, improves with time, and "attack from below" a traditional market (Christensen 1997). It is equally possible that a discontinuity with higher cost and performance (e.g., electronic calculator or fuel injection) is introduced into the high end market, lowers in cost and will "attack from above" the mass market. Discontinuities exist 
for all combinations of initial cost, performance, and benefits as compared to the traditional market version. The key factor is that the discontinuity enlarges and broadens markets and provides new functionality (Utterback \& Acee 2005).

The type of discontinuity can be speciation, convergence, or fusion (Adner \& Levinthal 2002). Speciation is applying an existing technology to a new application domain. For example, Software Engineering was created as "the application of engineering to software" (http://wnw.computer.org/portal/web/swebok/html/ch1). Speciation has two critical features: 1) The deviation will be minor in the beginning, and 2) The new technology creates a separate evolutionary path which allows the two populations to grow quite distinctly. "Creative destruction" occurs when the new technology invades other niches and may even substitute the original domain technology (Adner \& Levinthal 2002). The substitution of a technology by one of its speciation's is an explanation of disruptive innovation (Christensen \& Rosenbloom 1995).

Convergence is enhancing an existing technology with technology from a different domain, such as when the manufacturing technologies (e.g., drilling, planning, grinding, and polishing) for different industries (e.g., firearms, bicycles, and sewing machines) began to converge. Not only did the new technologies enhance the industries to which they were applied, but they created "vertical 
disintegration", thus creating of separate companies for specific processes in the product manufacturing (Rosenberg 1963).

Fusion is combining two or more technologies from different domains to create an application in a different domain, such as the creation of the liquid crystal display that was the combination of electronics, crystal, and optics technologies. Three principles that are essential for technology fusion are: 1) The R\&D agenda must be driven by the market, 2) The company must develop strong intelligence gathering capabilities involving all employees, and 3) Active participation with a variety of companies in many different industries on research consortia, joint ventures, and partnerships where risks and rewards are shared (Kodama 1992, Kodama 1993).

During the period of fermentation, there are many competing designs and the competition results in the technology making the majority of its technical progress. The discontinuities that trigger the fermentation periods never become the dominant designs and dominant designs lag behind the leading edge technologies (Anderson \& Tushman 1990).

The selection of the dominant design (diffusion) is:

- A factor of the innovation ("an idea, practice, or object that is perceived as new") 
- Communication channels (information available about the new technology how to use it and what it does)

- Time (how quickly the innovation is adopted by individuals)

- Social system (different groups, with different goals and abilities, approach technology differently) (Rogers 1995; Geroski 2000).

There is no guarantee that a dominant design will emerge. For example: antivirus software, camera phones, food processors, and instant messengers do not have dominant designs. The emergence of a dominant design in an industry has a strong and significant effect on firms' survival. If a dominant design has emerged, competition is no longer about design but about price, where incumbents drive to reduce costs through process innovations such as economies of scale, and generalized equipment (Suarez \& Utterback 1995). Sales always peak after a dominant design is selected, due to the reduction of technology uncertainty (Anderson \& Tushman 1990).

\subsection{CEA Market offers}

The construction of market offers for a communication enabled application is no different than that construction of a market offer for any other product or service. A market offer is a combination of the tangible and intangible features of a product (Levitt 1980). The tangible features are the attributes that can be 
measured (e.g., height, weight, colour, warranty, age of the manufacture). The intangible features are the attributes that are subjective (e.g., reputation, trust, the ability to deliver on promises, how the product is distributed).

Market offers can be viewed from a number of perspectives: 4Ps (product, price, place, and promotion), 7Ps (product, price, place, promotion, personnel, process, and physical evidence), $4 \mathrm{Cs}$ (customer needs, cost to customer, convenience, and communication), 4As (acceptability, affordability, accessibility, and awareness), alternate 4Ps (people, processes, programs, and performance), and 4Rs (receptivity, readiness, resources, and risk) (Kotler 2006).

The most common perspective is to view market offers at five levels: the core benefit, the generic product, the expected product, the augmented product, and the potential product (Kotler 2007).

"Companies don't sell drills, they sell holes." (Levitt 1990) The core benefit is the reason people buy the product, and the marketers must see themselves as benefit providers (Kotler 2007). For example, a hotel guest is buying "rest and sleep". A credit card holder is buying revolving credit facility, and a cell phone user is buying mobile communication.

The generic product is the product that meets the minimum needs of the core benefit. The "table stakes of business, what's needed for a chance to play the 
game of market participation" (Levitt 1980) For example, a hotel room with a bed, a credit card with a line of credit, and a cell phone that has wireless connection. Companies do not compete on the generic product, all hotel rooms have a place to sleep, all credit cards offer credit, and all cell phones make phone calls. Companies compete on meeting and exceeding their customer's expectations. Even generic products are not always comparable, just as a person who has a black belt in karate is not the same as a person with a black belt in judo.

The expected product contains all of the attributes and conditions of the product that the customer would consider essential and would thus agree to when purchasing the product (Levitt 1980). For example, a quiet room with a clean bed, fresh towels, working lamps, and dressers; a credit card, with a line of credit, and required operational and safety features; and a cell phone with a unique phone number and a local calling area. The expected product includes all the features that are assumed to be present. The expectation can vary by price range (e.g., the expectation for a five star hotel room is different than a one star), location (e.g., the expectation for cell phone in Asia are different than the ones in North America), time (e.g., the expectation of a home phone to have rotary dial replaced with a tone dial), competitive conditions (e.g., a large company or large number of companies adopt a feature) and more. 
Any product features that exceed the ones that are expected by customers, augment the product, and are a result of a mature market or sophisticated users (Levitt 1980). The augmentation can be functionality(e.g., one-touch emergency calling on a cell phone), product ethics (Crane 2001; Kotler 2004), an extended warranty, faster customer service, flexible payment plans, customer feedback methods, or anything else that adds addition value to the customer. In a competitive market, product differentiation usually occurs at the augmentation level, and current augmentations become expectations.

Even within a class of features, some features can be considered expected and others can be considered augmented. For example, according to Goyal (2006) most supplementary services of credit cards in India are considered expected (zero/limited lost card liability, acceptance of credit card at airlines and railway counters, and gas pumps, cash withdrawal within credit limit, joint credit card and ATM facility), while others are augmented features (the facilities of insurance on lost baggage during air travel, cash advance independent of credit limit, purchase protection on loss or damage from fire for items purchased through credit card).

The potential product is a collection of all of the features that could be delivered (Levitt 1980). 
Anything that can be imagined can be added. The only limitations are the budget and what makes the most economic sense to become more competitive.

As augmented features become expected, and known potential features become product augmentations, the marketer's task is to determine through conversations with customers what potential product(s) would gain and retain more customers. A common method to gather potential product information is to work with "Lead Users". Lead Users are users that 1) face needs that will be general in a market segment significantly earlier than the majority of the users in that market segment, and 2) are positioned to benefit significantly by obtaining a solution to those needs. Lead Users have an understanding of the problems that the rest of the segment will encounter in the future, and are motivated to solve the problems now (Von Hippel 1986).

If you consider that a potential portfolio contains a combination of potential products, for a relatively small number of features the number of possible portfolios can grow very quickly. For example, if there is currently only one product and there are three potentially new features, then there are seven potential products $\left(2^{3}-1\right)$ and at most 127 potential product portfolios $\left(2^{7}-1\right)$. In actual fact, the number of viable portfolios will be considerably less (i.e., a portfolio that contains products that cannibalize each other would not be a wise business decision). Chen, Carrillo, Vakharia \& Sin (2010) determined that the 
optimal portfolio of multifunction products depends on the profit margin and substitution effects (i.e., one potential product in a potential portfolio can be substituted for another). It was found that:

- If a multifunction product has relatively high margins, then this product likely dominates the product portfolio.

- When a single function product has relatively high profit margins, then it is less likely that a multifunction product containing this function should be offered. In this case, the firm should design and offer the single function product independently and combine other lower margin functions into a multifunction product.

- Small changes in the profit margin and/or substitution effect can cause large changes in the optimal product portfolio.

- When substitution effects are relatively high, a portfolio containing a smaller number of products is more likely to be optimal.

- When substitution effects are relatively low, then the optimal product portfolio is generally larger in size and more sensitive to small changes in profit margins. 


\subsection{Lessons Learned}

Mashups are a rapidly growing form of API integration, providing both examples of convergence and fusion. Examples of convergence includes: "Highest Hits Videos", a YouTube video search application that enables users to share videos and place comments on Facebook (http://unw.programmableweb.com/mashup/highest-hits-videos). Examples of fusion include "Mood Music", a site that plays music appropriate for the weather at your location (http://www.programmableweb.com/mashup/mood-music).

CEAs provide a new area of research. There is currently no academic literature on the topic. Most of the professional literature on the topic is the result of collaborations between Nortel, IBM, Microsoft, and Hewlett-Packard. Though there are anecdotal examples of CEAs, mostly integrating voice communication with IT applications, there is no classification of the types of CEAs.

Technology evolves in a fairly predictable cyclical pattern. There is a dominant design, slow steady improvement (mostly process innovation), technological discontinuity, fermentation (mostly product innovations), and then dominant design (usually only one). What is not predictable are the time periods for the stages (e.g., how long will a dominant design last?), if a new dominant design will emerge (e.g., the Dvorak keyboard never replaced the standard QWERTY 
keyboard), or if only one dominant design will emerge (e.g., there is no dominant design for cell phone application development).

Features in market offers are constantly changing. Some features of a potential product are added to an existing product, creating an augmented product that is intended to provide the manufacture with a competitive advantage. If enough existing products contain a feature, that feature becomes part of the expected product and is no longer a point of differentiation.

There is a relationship between technology evolution and market offers. Technology convergence creates an augmented product by enhancing the existing technology with technology from a different domain. Similarly, technology fusion combines previously separate technologies to create a new generic product. 


\section{RESEARCH METHOD}

Chapter 3 describes the method used to carry out this exploratory research. It is organized into three sections. Section 3.1 describes the research approach.

Section 3.2 provides the research design. Section 3.3 describes the steps undertaken to carry out the research.

\subsection{Research approach}

The research approach implemented has two parts:

1. Gather a sample of CEA mashups and identify mashup types

2. For each CEA mashup type identified, define the value it provides customers

Figure 1 illustrates the first part of the research approach. The outcome of the first part is to identify mashup types. This will be accomplished by classifying the API categories defined in the ProgrammableWeb into two classifications: IT or Communication. A computer program created by the researcher will then use the APIs in those categories to search for (deduce) CEA mashup types. 
The objective of the second part is to examine the websites of suppliers of mashups to identify, through induction, the value each CEA mashup type provides. This will be accomplished by using the "General Inquirer" program to analyse the mashup descriptions and tags. The General Inquirer program categorizes words according to a number of sources including: the Harvard IV-4 dictionary, and the Lasswell value dictionary.



Figure 1 - Research approach part 1 


\subsection{Research design}

\subsubsection{Unit of Analysis}

The unit of analysis of this research is a Communication Enabled Application mashup (e.g., component or system that is a combination of at least one IT API and at least one Communication API).

\subsubsection{Time Period}

The data will be collected during the months of February and March of 2011. The data collected covers the period February $27^{\text {th }}$ to March $27^{\text {th }}$.

\subsubsection{Sample}

The unit of analysis will be mashups from the ProgrammableWeb website at http://www.programmableweb.com.

There are a number of ways of locating CEA mashups.

- Investigate each mashup to determine if it is a CEA mashup. This approach would provide the best results, because it would locate every CEA mashup at the time of the investigation. Given that at the time of this writing (March 2011) the ProgrammableWeb.com contains over five thousand mashups, it is 
not feasible to investigate every one of them manually. An automated process to carry out this task does not exist.

- First examine each API and place it into one of four categories: (i) Communication, (ii) IT, (iii) Both, or (iv) Neither. Then find every mashup that use at least one API from each API category. This approach should provide most CEA mashups, only missing mashups that use only APIs in the "Both" category. There are over three thousand APIs; therefore it would be difficult to investigate each one manually.

- Investigate each category of the ProgrammableWeb's segments and classify the entire category as (i) Communication, (ii) IT, (iii) Both, or (iv) Neither category (e.g., category like "auctions" with no APIs), and then find every mashup that uses at least one API from each category classification.

The last approach should provide a large sample of CEA mashups. There are only fifty three API categories, making this approach much more manageable.

The sample is comprised of APIs drawn from the ProgrammableWeb website. The APIs in the sample are those that are part of a Communication category (e.g., Chat) or an IT category (e.g., Shopping). The categories and the numbers of APIs that existed in the ProgrammableWeb website at the time of this writing (March 2011) was: 
Advertising (40), Answers (9), Blog Search (8), Blogging (35), Bookmarks (25), Calendar (10), Chat (27), Database (24), Dating (1), Dictionary (2), Email (60), Enterprise (109), Events (21), Fax (5), Feeds (17), File Sharing (11), Financial (126), Food (11), Games (37), Government (66), Internet (230), Job Search (22), Mapping (173), Media Management (12), Medical (15), Messaging (89), Music (89), News (37), Office (26), Other (148), Payment (43), Photos (81), PIM (17), Project Management (31), Real Estate (33), Recommendations (35), Reference (131), Retail (2), Search (98), Security (49), Shopping (120), Social (204), Sports (31), Storage (36), Tagging (11), Telephony (125), Tools (107), Travel (60), Utility (56), Video (91), Weather (14), Widgets (25), Wiki (10)

\subsection{Research steps}

Table 1 provides an overview of the steps undertaken to carry out this research. 


\begin{tabular}{|c|c|c|c|}
\hline & Step & Dominant activity undertaken & Deliverable \\
\hline 1 & $\begin{array}{l}\text { Creation of API } \\
\text { classifications } \\
\text { definitions }\end{array}$ & $\begin{array}{l}\text { Develop definitions for IT and } \\
\text { Communication APIs }\end{array}$ & $\begin{array}{l}\text { Version } 1 \text { of the } \\
\text { definitions of } \\
\text { Communication and IT } \\
\text { APIs }\end{array}$ \\
\hline 2 & $\begin{array}{l}\text { Independent } \\
\text { verification of } \\
\text { classification } \\
\text { definitions } \\
\end{array}$ & $\begin{array}{l}\text { Obtain agreement on definitions } \\
\text { with } 4 \text { other TIM students/alumni } \\
\text { and update definitions }\end{array}$ & $\begin{array}{l}\text { Version } 2 \text { of the } \\
\text { definitions of } \\
\text { Communication and IT } \\
\text { APIs }\end{array}$ \\
\hline 3 & \begin{tabular}{|l|} 
Classify API \\
categories \\
according to \\
agreed definitions
\end{tabular} & $\begin{array}{l}\text { Given agreed definitions all five } \\
\text { TIM professionals classify all } \\
\text { ProgrammableWeb API } \\
\text { categories into Communication, } \\
\text { IT, both, or neither. }\end{array}$ & $\begin{array}{l}\text { Version } 1 \text { of } \\
\text { Communication and IT } \\
\text { API categories }\end{array}$ \\
\hline 4 & $\begin{array}{l}\text { Consolidate } \\
\text { classifications }\end{array}$ & $\begin{array}{l}\text { For each ProgrammableWeb API } \\
\text { category, assign the classification } \\
\text { that the majority of TIM } \\
\text { professionals have indicated. }\end{array}$ & $\begin{array}{l}\text { Version } 2 \text { of } \\
\text { Communication and IT } \\
\text { API categories }\end{array}$ \\
\hline 5 & $\begin{array}{l}\text { Create an } \\
\text { automated CEA } \\
\text { mashup test }\end{array}$ & $\begin{array}{l}\text { Create a computer program to } \\
\text { produce a table containing the } \\
\text { count of mashups for the } \\
\text { Communication categories } \\
\text { versus the IT categories }\end{array}$ & $\begin{array}{l}\text { Version } 1 \text { of a test to } \\
\text { decide whether or not a } \\
\text { mashup is a CEA (each } \\
\text { cell that is non-zero is a } \\
\text { CEA mashup type) }\end{array}$ \\
\hline 6 & Consult experts & $\begin{array}{l}\text { Have the definitions, } \\
\text { classifications and CEA mashup } \\
\text { types validated by five CEA } \\
\text { experts }\end{array}$ & $\begin{array}{l}\text { Version } 2 \text { of a test to } \\
\text { decide whether or not a } \\
\text { mashup is a CEA }\end{array}$ \\
\hline 7 & $\begin{array}{l}\text { Update CEA } \\
\text { mashup types }\end{array}$ & $\begin{array}{l}\text { Rerun the program based on the } \\
\text { feedback from the experts }\end{array}$ & $\begin{array}{l}\text { Improved CEA mashup } \\
\text { test and types (Version } \\
\text { 3) }\end{array}$ \\
\hline 8 & Text analysis & $\begin{array}{l}\text { For each CEA mashup type, run } \\
\text { an analysis of the text from the } \\
\text { mashup descriptions, and tags } \\
\text { using the General Inquirer tag } \\
\text { categories that indicate value. }\end{array}$ & $\begin{array}{l}\text { CEA mashup types } \\
\text { based on their suppliers' } \\
\text { statements of customer } \\
\text { value }\end{array}$ \\
\hline
\end{tabular}

Table 1 - Research steps 


\subsubsection{Step 1: Creation of API classifications definitions}

The definitions of what constitutes a Communication API and an IT API were created by the researcher summarizing the examples provide in literature on Communications Enabled Application including the Wikipedia entry on this topic.

\subsubsection{Step 2: Independent verification of classification definitions}

To successfully complete this step, the following tasks will be carried out:

1. Select four TIM students or TIM alumni who:

- Have worked in the IT or Telecom industry for more than five years

- Have successfully completed (in the last six months) or are about to complete (in the next six months) a thesis that examines mashups

2. Request assistance with the thesis, explaining the tasks that they will be required to provide and the need to have their task completed in a week.

3. For each student that declines, repeat task one with one more TIM student

4. For each student that accepts, send the definitions created in the previous step by email 
5. Using email, clarify definitions until all five professionals agree that they understand the definitions and can use them to classify the categories.

\subsubsection{Step 3: Classify API categories according to agreed definitions}

In this step, the following tasks will be carried out:

1. Use the search utility on the API Directory of ProgrammableWeb website (http://www.programmableweb.com/apis/directory) to find all of the API categories

2. Create a list of all the categories in an excel spreadsheet

3. Email list to the four other TIM professionals identified in the previous step

4. Each professional (the researcher and the four others) will do a search (using the above API Directory) of the APIs that the category contains, and assign the category to one of the four classifications:

Communication - if the category only contains communication APIs, based on the agreed definitions in step two.

IT - if the category only contains only IT APIs, based on the agreed definitions in step two.

Both - if the category contains both Communication and IT APIs 
Neither - if the category contains neither Communication nor IT APIs, or contains no APIs

\subsubsection{Step 4: Consolidate classifications}

When all four professionals reply by email directly to the researcher without CCing the other, the researcher will consolidate the classifications. For each category, classifications will be selected based on three out of five professionals selecting it. Should a category not receive the required three votes; it will be excluded from future steps.

\subsubsection{Step 5: Create an automated CEA mashup test}

A program will be created by the researcher to find all mashups that contain APIs in both categories; and to create a table similar to Table 2 . 


\begin{tabular}{|c|c|c|c|c|c|}
\hline & \multicolumn{4}{|c|}{ Communication Categories } \\
\hline & & $\begin{array}{c}\text { Comm } \\
\text { Category } 1\end{array}$ & $\begin{array}{c}\text { Comm } \\
\text { Category } 2\end{array}$ & $\begin{array}{c}\text { Comm } \\
\text { Category } 3\end{array}$ & $\begin{array}{c}\text { Comm } \\
\text { Category } 4\end{array}$ \\
\hline \multirow{3}{*}{$\begin{array}{c}\text { IT } \\
\text { Categories }\end{array}$} & $\begin{array}{c}\text { IT } \\
\text { Category } \\
1\end{array}$ & & & $\begin{array}{l}\text { CEA Mashup } \\
\text { type } 1 \text { count }\end{array}$ & \\
\hline & $\begin{array}{c}\text { IT } \\
\text { Category } \\
2\end{array}$ & & & & \\
\hline & $\begin{array}{c}\text { IT } \\
\text { Category } \\
3\end{array}$ & $\begin{array}{l}\text { CEA Mashup } \\
\text { type } 2 \text { count }\end{array}$ & & $\begin{array}{l}\text { CEA Mashup } \\
\text { type } 3 \text { count }\end{array}$ & \\
\hline
\end{tabular}

Table 2 - CEA mashups based on communication and IT categories

In an attempt to find "prototypical members" (Rosch 1999), when the creation of Table 2 has been completed, Table 3 will be created where each cell that contains an average or greater number of mashups (i.e., number of mashups found / number of cell that contain at least one mashup) will be assigned a unique CEA mashup type name by the researcher. 


\begin{tabular}{|c|c|c|c|c|c|}
\hline \multicolumn{2}{|c|}{} & \multicolumn{4}{|c|}{ Communication Categories } \\
\cline { 2 - 6 } & $\begin{array}{c}\text { Comm } \\
\text { Category 1 }\end{array}$ & $\begin{array}{c}\text { Comm } \\
\text { Category 2 }\end{array}$ & $\begin{array}{c}\text { Comm } \\
\text { Category 3 }\end{array}$ & $\begin{array}{c}\text { Comm } \\
\text { Category 4 }\end{array}$ \\
\hline \multirow{4}{*}{$\begin{array}{c}\text { IT } \\
\text { Categories }\end{array}$} & $\begin{array}{c}\text { IT } \\
\text { Category } \\
1\end{array}$ & & & $\begin{array}{c}\text { CEA Mashup } \\
\text { type 1 name }\end{array}$ & \\
\cline { 2 - 6 } & $\begin{array}{c}\text { IT } \\
\text { Category }\end{array}$ & & & & \\
\cline { 2 - 6 } & $\mathbf{2}$ & & & & \\
\cline { 2 - 6 } & IT & & & \\
& Category & CEA mashup & & & \\
& type 2 name & & & \\
\hline
\end{tabular}

Table 3 - CEA mashup types based on communication and IT categories The created program will serve two purposes:

1. Given one Communication category and one IT category find all mashups that use at least one API from each category (e.g., find all mashups that use a Telephony API and an Enterprise API)

2. Given a mashup determine if it is a CEA mashup (examine each of the APIs that form the mashup, for each API determine its category and then its category classification. If it contain at least one API that is classified as a Communication API and one IT classified API, then it is a CEA mashup otherwise it is not) (e.g., "Phone2Lead Call Tracking with Salesforce" 
http://nww.programmableweb.com/mashup/phone2lead-call-tracking-withsalesforce would be a CEA mashup since it is composed of "Salesforce.com"\{Enterprise/IT API $\}$ and "Twilio" $\{$ Telephony /Communications API\})

\subsubsection{Step 6: Consult experts}

The classifications and Table 3 will be presented to five individuals who have developed or sold a CEA for more than two years. Each individual will be asked to validate the results of steps 4 and 5 based on their own experience The feedback from the experts will be recorded and a decision as the proper CEA test will be agreed to by the majority of the experts. The experts will be asked:

1. Given the step 2 definitions, do they agree with the results of step 4 ?

2. Do they agree with the identified CEA mashup types resulting from step $5 ?$

\subsubsection{Step 7: Update CEA mashup types}

The researcher will review the feedback from the experts, and update Table 3 if necessary. If the majority of the experts agree that certain categories should be added or removed from the Communications or IT classifications, the program will be updated accordingly and a new version of Table 3 will be created. If the 
majority of the experts agree that certain CEA mashup types should be added or removed, some investigation (subject to available time) will be done to identify the discrepancy, but Table 3 will not be modified.

\subsubsection{Step 8: Text analysis}

For each CEA mashup type identified in step 7, the following tasks will be done:

1. The description and tags from all the ProgrammableWeb mashup pages of that CEA mashup type are entered into the "General Inquirer" (GI) program (http://webgi.stone-center.eu/index.php) and the "Submit Query" button is pressed.

2. A column will be added to Table 4 with the resulting values and percentages from the General Inquirer query.

\begin{tabular}{|c|c|c|c|}
\hline & Type A & Type B & Type C \\
\hline GI Value 1 & $\begin{array}{c}\text { Type A value } 1 \\
\text { percentage }\end{array}$ & $\begin{array}{c}\text { Type B value } 1 \\
\text { percentage }\end{array}$ & $\begin{array}{c}\text { Type } \mathrm{C} \text { value } 1 \\
\text { percentage }\end{array}$ \\
\hline GI Value 2 & $\begin{array}{c}\text { Type A value } 2 \\
\text { percentage }\end{array}$ & $\begin{array}{c}\text { Type B value } 2 \\
\text { percentage }\end{array}$ & $\begin{array}{c}\text { Type } \mathrm{C} \text { value } 2 \\
\text { percentage }\end{array}$ \\
\hline GI Value 3 & $\begin{array}{c}\text { Type A value } 3 \\
\text { percentage }\end{array}$ & $\begin{array}{c}\text { Type B value } 3 \\
\text { percentage }\end{array}$ & $\begin{array}{c}\text { Type } C \text { value } 3 \\
\text { percentage }\end{array}$ \\
\hline
\end{tabular}

Table 4 - CEAs based on mashup type and supplier stated values 


\section{RESULTS}

Chapter 4 is organized into four sections. Section 4.1 provides the Communication and IT classification developed. Section 4.2 describes the CEA mashup types identified. Section 4.3 provides the values of the CEA mashup types. Section 4.4 presents the main findings of this research.

\subsection{Classification Development}

\subsubsection{Outcome of step 1: Creation of API classifications definitions}

The outcome of Step 1 was the initial definitions of IT and Communication APIs. The definitions developed by the researcher were:

An IT API provides access to the acquisition, processing, storage and dissemination of vocal, pictorial, textual and numerical information, with no regard to the transmission of this information.

A Communication API provides the control and monitoring of the transmission of information. 


\subsubsection{Outcome of step 2: Independent verification of classification definitions}

Four professionals helped improve the definitions of IT and Communication APIs produced in Step 1. Of the four, two successfully completed their theses in M.A.Sc. in Technology Innovation Management. The third has over 20 years experience in the field of telecommunications. Finally, the fourth has been a team leader for a number of major IT projects in the Canadian government over the last seven years

The general consensus was that parts of the definitions were considered too vague (e.g., "with no regard to the transmission of this information") and through email discussions the definitions were clarified. The revised definitions to which all four individuals agreed were:

IT API - An application interface that provides access to the acquisition, processing, storage, and dissemination of data with no control over the channel of its transmission.

Communication API - An application interface that provides the control and monitoring of a channel used for the transmission of data. 


\subsubsection{Outcome of step 3: Classify API categories according to agreed definitions}

Table 5 provides the outcome of Step 3. For each API category of the ProgrammableWeb, Table 5 shows the assessments of the five professionals as to whether it was IT, Communications or both.

The category numbers in the first column of Table 5 are added to assist in the explanations of further steps in this section. The last column in Table 5 provides the decision of the majority. If there was no majority decision, the API category was shown as unknown. 


\begin{tabular}{|c|c|c|c|c|c|c|}
\hline \multirow[b]{2}{*}{$\begin{array}{l}\text { Category } \\
\text { \# }\end{array}$} & \multirow[b]{2}{*}{$\begin{array}{l}\text { Category } \\
\text { Name }\end{array}$} & \multicolumn{5}{|c|}{ Professional } \\
\hline & & Researcher & One & Two & Three & Four \\
\hline 1 & Advertising & Both & IT & IIT & IIT & IIT \\
\hline 2 & Answers & Both & IT & IT & IT & Both \\
\hline 3 & Blog Search & IT & IT & Both & IT & IT \\
\hline 4 & Blogging & Both & IT & IT & IT & Both \\
\hline 5 & Bookmarks & Both & IT & IT & IT & IT \\
\hline 6 & Calendar & IT & IT & IT & IT & IIT \\
\hline 7 & Chat & Comm & Both & Comm & Comm & Comm \\
\hline 8 & Database & IT & IT & IT & Both & IT \\
\hline 9 & Dating & Both & IT & Comm & ITT & Comm \\
\hline 10 & Dictionary & IT & IIT & IT & ITT & IIT \\
\hline 11 & Email & IT & Both & Both & Comm & IIT \\
\hline 12 & Enterprise & IT & IT & Both & Comm & IIT \\
\hline 13 & Events & IT & IT & IT & Both & IT \\
\hline 14 & Fax & IT & Both & Both & Comm & Both \\
\hline 15 & Foeds & Both & IT & Comm & Comm & IT \\
\hline 16 & File Sharing & IT & Both & Both & Comm & Both \\
\hline 17 & Financial & IIT & IIT & IT & Both & Both \\
\hline 18 & Food & IIT & IT & IT & Both & Both \\
\hline 19 & Games & IT & IT & IT & Both & Both \\
\hline 20 & Government & IT & IT & IT & Both & IT \\
\hline 21 & Internet & IT & IT & Both & Both & Both \\
\hline 22 & Job Search & IT & IT & IT & IT & IT \\
\hline 23 & Mapping & Both & Both & Both & Both & IT \\
\hline 24 & \begin{tabular}{|l|} 
Media \\
Management
\end{tabular} & IT & IT & Both & IT & IIT \\
\hline 25 & Medical & IT & IT & IT & Both & IT \\
\hline 26 & Messaging & Comm & Both & Comm & Both & Comm \\
\hline 27 & Music & IT & Both & Both & Comm & IT \\
\hline 28 & News & IT & IT & Both & Comm & IT \\
\hline 29 & Office & IT & IT & Both & IT & IT \\
\hline 30 & Other & Both & Both & IT & IT & IT \\
\hline 31 & Payment & IIT & IT & IT & IT & IT \\
\hline 32 & Photos & IT & IT & IT & IIT & Both \\
\hline 33 & PIM & IIT & IT & IT & Both & Both \\
\hline 34 & Project & IT & IT & IT & IT & IIT \\
\hline
\end{tabular}




\begin{tabular}{|l|l|l|l|l|l|l|}
\hline & & \multicolumn{5}{|c|}{ Professional } \\
\hline $\begin{array}{l}\text { Category } \\
\text { Category }\end{array}$ & $\begin{array}{l}\text { Researcher } \\
\text { Name }\end{array}$ & One & Two & Three & Four \\
\hline & Management & & & & & \\
\hline 35 & Real Estate & IT & IT & IT & IT & IT \\
\hline 36 & $\begin{array}{l}\text { Recommendat } \\
\text { ions }\end{array}$ & & & & & \\
\hline 37 & Reference & IT & IT & IT & IT & IT \\
\hline 38 & Retail & IT & IT & IT & IT & IT \\
\hline 39 & Search & IT & IT & IT & Both & IT \\
\hline 40 & Security & IT & IT & IT & Comm & IT \\
\hline 41 & Shopping & IT & IT & IT & Both & IT \\
\hline 42 & Social & Both & IT & Both & IT & Both \\
\hline 43 & Sports & IT & IT & IT & IT & IT \\
\hline 44 & Storage & IT & Both & Both & IT & IT \\
\hline 45 & Tagging & IT & IT & IT & IT & IT \\
\hline 46 & Telephony & Comm & Both & Comm & Comm & Both \\
\hline 47 & Tools & Both & IT & IT & Both & Both \\
\hline 48 & Travel & IT & IT & IT & IT & Both \\
\hline 49 & Utility & IT & IT & IT & IT & IT \\
\hline 50 & Video & IT & Both & Both & IT & Both \\
\hline 51 & Weather & IT & IT & IT & IT & IT \\
\hline 52 & Widgets & Both & IT & Both & Both & IT \\
\hline 53 & Wiki & IT & IT & IT & IT & IT \\
\hline
\end{tabular}

Table 5 - Classification of API categories in the ProgrammableWeb

A total of 49 of the 53 API categories shown in Table 5 had a clear majority decision. The four that did not have a majority decision were:

- Dating - 2 IT, 1 Both, 2 Communications

- Email - 2 IT, 2 Both, 1 Communications 
- Feed - 2 IT, 1 Both, 2 Communications

- Music - 2 IT, 2 Both, 1 Communications

The researcher sent an email to the other four professionals stating "If no one has any strong objections I would like to mark all four of them as 'Both', and say that this step is complete". No objections were received. Thus, the majority decision for API categories identified as "Unknown" became "Both".

\subsubsection{Outcome of step 4: Consolidate classifications}

Table 6 was the outcome of Step 4. Table 6 shows the "IT" and "Communication" categories ("Both" categories have been removed since there is no obvious means of using "Both" categories to detect CEAs) used by the computer program to find CEA mashups. There are three pure Communication API categories and thirty eight pure IT API categories. This indicates a potential of one hundred and fourteen CEA mashups (i.e., $3 \times 38$ ).

\begin{tabular}{|l|l|}
\hline Category \# & Category Name \\
\hline 1 & Advertising \\
\hline 2 & Answers \\
\hline 3 & Blog Search \\
\hline 4 & Blogging \\
\hline 5 & Bookmarks \\
\hline 6 & Calendar \\
\hline 7 & Chat \\
\hline 8 & Database \\
\hline 10 & Dictionary \\
\hline
\end{tabular}




\begin{tabular}{|l|l|}
\hline Category \# & Category Name \\
\hline 12 & Enterprise \\
\hline 13 & Events \\
\hline 17 & Financial \\
\hline 18 & Food \\
\hline 19 & Games \\
\hline 20 & Government \\
\hline 22 & Job Search \\
\hline 24 & Media Management \\
\hline 25 & Medical \\
\hline 26 & Messaging \\
\hline 28 & News \\
\hline 29 & Office \\
\hline 30 & Other \\
\hline 31 & Payment \\
\hline 32 & Photos \\
\hline 33 & PIM \\
\hline 34 & Project Management \\
\hline 35 & Real Estate \\
\hline 36 & Recommendations \\
\hline 37 & Reference \\
\hline 38 & Retail \\
\hline 39 & Search \\
\hline 40 & Security \\
\hline 41 & Shopping \\
\hline 43 & Sports \\
\hline 44 & Storage \\
\hline 45 & Tagging \\
\hline 46 & Tolephony \\
\hline 48 & Travel \\
\hline 49 & Utility \\
\hline 51 & Weather \\
\hline 53 & Wiki \\
\hline & \\
\hline
\end{tabular}

Table 6 - ProgrammableWeb final category classification 


\subsection{CEA Mashup Type Identification}

\subsubsection{Outcome of step 5: Create an automated CEA mashup test}

Table 7 was the outcome of the first part of Step 5, to determine the number of CEA mashup types that contain at least one IT and one communication API. The category numbers are the ones assigned in Table 6 for the purpose of creating a cross reference back to that table. The numbers in the cells show the count of mashups of the type that use at least one API from the corresponding Communication category (columns) and the IT category (rows). Blank cells indicate that there are no mashups of the specified type.

Of the potential 114 CEA mashups, Table 7 shows that there are only 62 CEA mashups. 


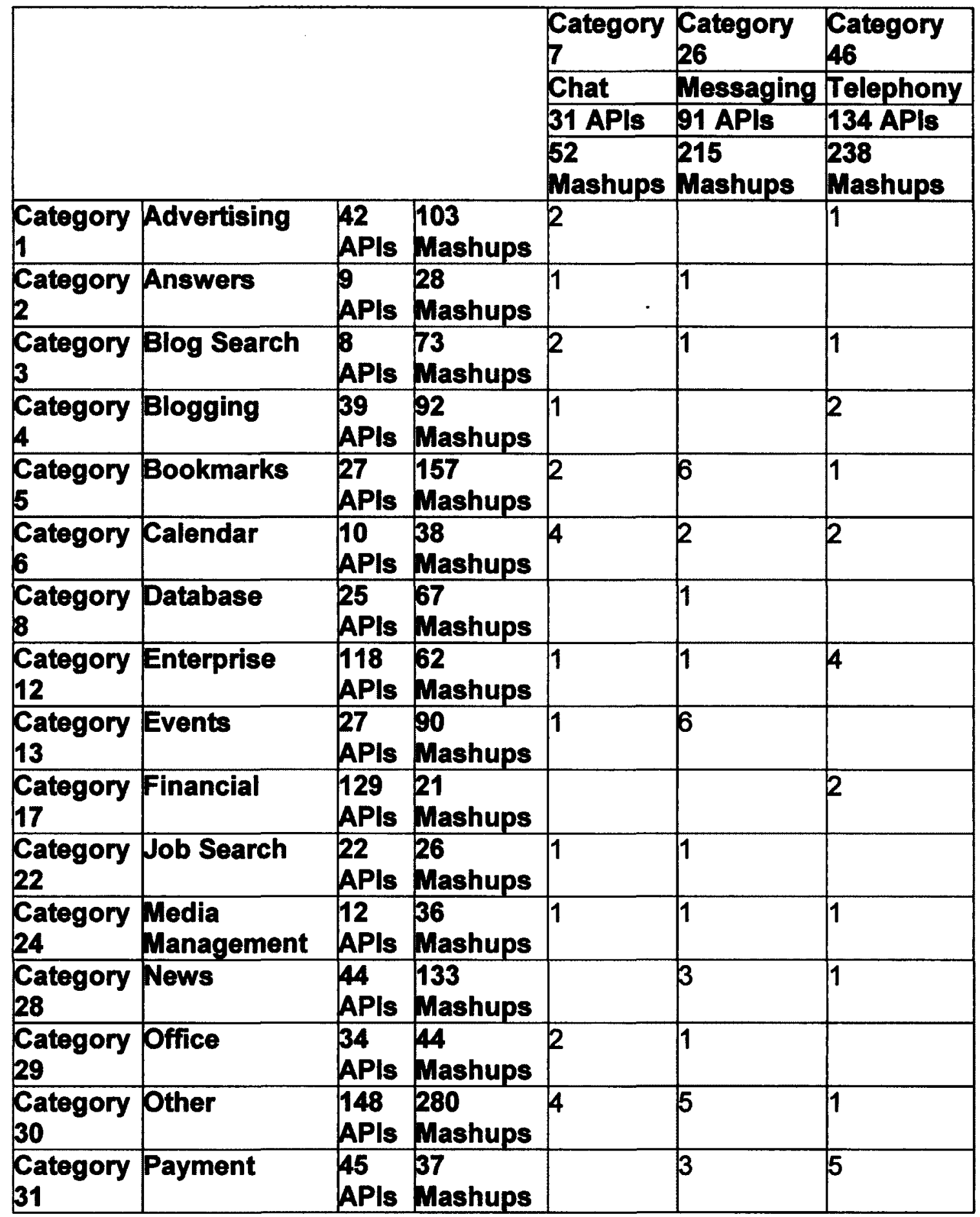




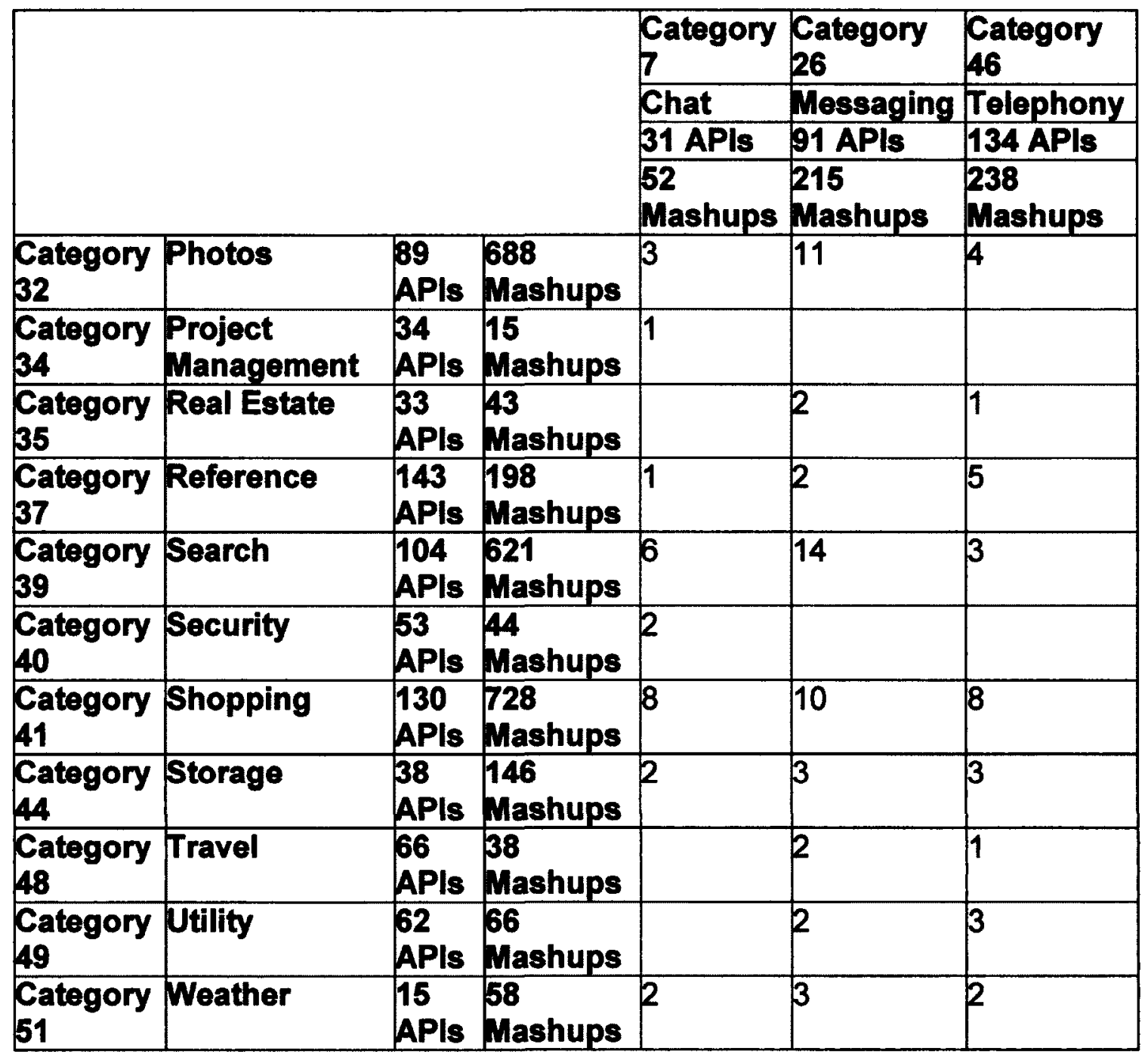

Table 7 - Automated CEA mashup initial results

Table 8 was the outcome of second part of Step 5. Per the tasks in step 5, Table 8 only assigns unique names to CEA Mashup types that have more than two mashups (179 total CEA mashups/62 CEA mashup types $=2.89$ average CEA mashups/CEA mashup type), this reduced the number CEA mashup types to 
twenty three, with all three Communications categories and fourteen of the thirty eight IT categories.

The researcher created Table 8 by examining the ProgrammableWeb descriptions for all of the mashups in each mashup type, and assigning a unique name that characterized that type. (e.g., all four mashups that used "Enterprise" and "Telephony" APIs used a telephony API to enhance the SalesForce API, therefore the researcher assigned the name "Sales telephony" to this type). The cells of Table 8 are these researcher assigned names. 


\begin{tabular}{|c|c|c|c|c|}
\hline & & Category 7 & Category 26 & Category 46 \\
\hline & & Chat & Messaging & Telephony \\
\hline Category & Bookmarks & & Data aggregator & \\
\hline $\begin{array}{l}\text { Category } \\
6\end{array}$ & Calendar & Personal organizer & & \\
\hline \begin{tabular}{|l} 
Category \\
12
\end{tabular} & Enterprise & & & Sales telephony \\
\hline \begin{tabular}{|l} 
Category \\
13
\end{tabular} & Events & & Mobile event search & \\
\hline \begin{tabular}{|l} 
Category \\
28 \\
\end{tabular} & News & & Mobile news search & \\
\hline $\begin{array}{l}\text { Category } \\
30\end{array}$ & Other & Personal Chat & $\begin{array}{l}\text { Personal } \\
\text { notifications }\end{array}$ & \\
\hline $\begin{array}{l}\text { Category } \\
31\end{array}$ & Payment & & $\begin{array}{l}\text { Payment enhanced } \\
\text { messaging }\end{array}$ & $\begin{array}{l}\text { Payment enhanced } \\
\text { telephony }\end{array}$ \\
\hline $\begin{array}{l}\text { Category } \\
32\end{array}$ & Photos & $\begin{array}{l}\text { Communication } \\
\text { enhanced photos }\end{array}$ & $\begin{array}{l}\text { Photo enhanced } \\
\text { mobility }\end{array}$ & $\begin{array}{l}\text { Photo enhanced } \\
\text { telephony }\end{array}$ \\
\hline $\begin{array}{l}\text { Category } \\
37\end{array}$ & Reference & & & $\begin{array}{l}\text { Communication } \\
\text { enhanced } \\
\text { education }\end{array}$ \\
\hline \begin{tabular}{|l|} 
Category \\
39
\end{tabular} & Search & Personal search & Mobile search & Telephony search \\
\hline $\begin{array}{l}\text { Category } \\
41\end{array}$ & Shopping & $\begin{array}{l}\text { Communication } \\
\text { enhanced } \\
\text { shopping }\end{array}$ & Mobile shopping & $\begin{array}{l}\text { Telephony } \\
\text { enhanced shopping }\end{array}$ \\
\hline \begin{tabular}{|l|} 
Category \\
44
\end{tabular} & Storage & & $\begin{array}{l}\text { Store and send } \\
\text { services }\end{array}$ & Telephony storage \\
\hline \begin{tabular}{|l|} 
Category \\
49
\end{tabular} & Utility & & & Telephony utilities \\
\hline \begin{tabular}{|l|} 
Category \\
51
\end{tabular} & Weather & & Weather notifier & \\
\hline
\end{tabular}

Table 8 - Initial CEA mashup types 


\subsubsection{Outcome of step 6: Consult experts}

Table 9 provides the outcome of Step 6. Table 9 shows the comments from the CEA experts, the general consensus was that the mashup descriptions did not provide sufficient information to accurately determine the purpose and functionality of the mashup. Most of the experts agreed that the mashups found were CEAs. Items in bold below are the researcher's interpretation of the questionnaire results completed by the experts. Items that are not in bold are direct copies of the emails from the experts (with the exception of the names removed). Note: some of the comments below may be off topic, but were included in their entirety for completeness of the feedback from the experts. 


\begin{tabular}{|c|c|}
\hline CEA Expert & Comment \\
\hline Expert 1 & $\begin{array}{l}\text { Based on your definition of a communication API, } \\
\text { the only category that I think matches that definition } \\
\text { is the Telephony category. None of the APIs in the } \\
\text { other categories appear to have anything to do with } \\
\text { the control or monitoring of a communications } \\
\text { channel - the Messaging and Chat categories only } \\
\text { allow people to share information and don't provide } \\
\text { any controls over the channel of transmission (the } \\
\text { Messaging one appears to be a bunch of APIs for } \\
\text { sending SMS over HTTP, and while the Chat APIs } \\
\text { do include things that I would categorize as } \\
\text { communication APIs, based on your definition I } \\
\text { would have to exclude them). This limits the } \\
\text { categories that match your definition of CEA } \\
\text { Mashup quite severely. } \\
\text { Another note is that some APIs have many aspects, } \\
\text { and some of the mashups appear to only use parts } \\
\text { of those APIs. As an example, while I could agree } \\
\text { with Skype as having aspects that are a Telephony } \\
\text { API, a mashup that updates the Skype mood field } \\
\text { does not fit into the Telephony category and calls } \\
\text { the use of contributor categorizations into question. } \\
\text { For the mashup types, perhaps it's my } \\
\text { communications background coming through, but } \\
\text { I'd start with that category generally. I struggled } \\
\text { with a number of these, they seem to be straining } \\
\text { the bounds of your definitions: } \\
\text { Oales telephony } \\
\text { Voice sales would be my alternate } \\
\text { suggestion here. } \\
\text { O Based on the apps referenced, I don't } \\
\text { see how payment comes into the mashup } \\
\text { except perhaps as a way to pay for the } \\
\text { use of the service. I don't think that this }\end{array}$ \\
\hline
\end{tabular}




\begin{tabular}{|c|c|}
\hline & $\begin{array}{l}\text { category is CEA based on the apps that } \\
\text { are here. } \\
\text { o Photo enhanced telephony } \\
\text { O Voice-enhanced photos, perhaps? } \\
\text { Communication enhanced education } \\
\text { O Perhaps Voice-enabled web reference? } \\
\text { o Telephony search } \\
\text { O OK } \\
\text { Oelephony enhanced shopping } \\
\text { O Another one where some of the apps I } \\
\text { APIs appear to be mis-categorized, which } \\
\text { throws me off completely. Voice-enabled } \\
\text { online shopping would be my suggestion } \\
\text { here for the ones that appear to be using } \\
\text { voice. } \\
\text { Telephony storage } \\
\text { This one really does not work for me. It } \\
\text { would be a fair editorial choice to exclude } \\
\text { storage from your list. } \\
\text { Telephony utilities } \\
\text { OK }\end{array}$ \\
\hline Expert 2 & $\begin{array}{l}\text { I think that your classifications look fine to me, I } \\
\text { changed a couple of the first ones as some of the } \\
\text { medical applications are indeed bi-directional } \\
\text { communication channels incorporating in-house } \\
\text { detection to provide remote monitoring and early } \\
\text { intervention. } \\
\text { Added "enterprise" and "medical" to the } \\
\text { communication classification } \\
\text { Accepted all of the mashup type names }\end{array}$ \\
\hline Expert 3 & $\begin{array}{l}\text { Not sure that I can help here as I don't know what } \\
\text { your list of APls do. I haven't coded in a long time } \\
\text { and never with these APls. So all I can do is judge } \\
\text { by their names, which is pretty limited. So, from } \\
\text { your list, I'd wonder whether Advertising, Blogging, } \\
\text { Calendar, Government, Media Management, } \\
\text { Recommendations, Wiki. Again, since I don't know }\end{array}$ \\
\hline
\end{tabular}




\begin{tabular}{|c|c|}
\hline & $\begin{array}{l}\text { what these do, I'm just wondering. } \\
\text { There's no way I can understand what these } \\
\text { mashups might do based on a one line description } \\
\text { and references to web services that I know to } \\
\text { varying degrees. (And your dreaming if you think } \\
\text { this is a half hour exercise. ) The ones that I read } \\
\text { and understood all sounded likely enough. If I } \\
\text { knew what these all did then I'd answer your } \\
\text { question in the following way: When I think of CEA } \\
\text { it is the Enabled part that is key. Is there a } \\
\text { business process or consumer activity that can be } \\
\text { made better somehow with real time, quality } \\
\text { communication/collaboration technology? That's } \\
\text { the question. ie you could perform the task without } \\
\text { CE but with CE it is a superior experience and there } \\
\text { are better or new opportunities to monetize. }\end{array}$ \\
\hline Expert 4 & $\begin{array}{l}\text { I've gone through the document and have added } \\
\text { suggestions where I could. I thought all of your } \\
\text { classifications looked right. I included a few } \\
\text { suggestions name changes that might be better, } \\
\text { but these things are always tricky, so you may not } \\
\text { agree. } \\
\text { I hope this helps. If there was something more I } \\
\text { was supposed to do, let me know. } \\
\text { Sale telephony }>\text { Integrated Sales Manager } \\
\text { Mobile news search }>\text { Mobile News Tracker } \\
\text { Payment enhance telephony }>\text { Pay-by-voice? } \\
\text { Photo enhanced mobility } \rightarrow \text { Photo enhanced } \\
\text { messaging } \\
\text { Personal search } \rightarrow \text { Enhanced search } \\
\text { Communication enhanced shopping } \rightarrow \text { Chat } \\
\text { enhanced shopping } \\
\text { Telephony storage } \rightarrow \text { Telephony accessible }\end{array}$ \\
\hline
\end{tabular}




\begin{tabular}{|c|c|}
\hline & cloud storage \\
\hline Expert 5 & $\begin{array}{l}\text { Got through it. Think I understand the concept so } \\
\text { here are my thoughts. First of all there are only two } \\
\text { communication API: verbal and non-verbal. Verbal } \\
\text { uses human speach for interaction and non-verbal } \\
\text { doesn't. I don't think anything beyond that makes } \\
\text { much sense. The difference between chat and } \\
\text { messaging for example is what? Whether or not } \\
\text { someone is at the device at that instant? For me } \\
\text { the real difference in communication methods is } \\
\text { whether or not you need to be physically in contact } \\
\text { with the communications device. With verbal } \\
\text { communications you do not have to be whereas } \\
\text { non-verbal you do or it's only } 1 \text {-way interaction } \\
\text { which I believe is an oxymoron. Verbal } \\
\text { communication can make very different demands } \\
\text { on the comm channel too. } \\
\\
\text { Second, I don't think there is any difference } \\
\text { between many of the mashup categories because } \\
\text { there's virtually no difference between the IT API } \\
\text { categories. Don't let the meaning of the data } \\
\text { confuse the issue; data is data. Whether you are } \\
\text { searching or just reading the news, you tell the } \\
\text { other end you want some data and it responds. } \\
\text { Another example is the difference between events } \\
\text { and personal notifications? The fact that one is } \\
\text { public and the other potentially private is about it. } \\
\text { Why not just have a single mashup? One of the } \\
\text { problems with all these different mashups is that } \\
\text { they won't be interchangeable. You could } \\
\text { potentially have to create two apps one for public } \\
\text { events and one for private events. Where is the } \\
\text { benefit in that? I think you have a great opportunity } \\
\text { here to look at what's going on and create a } \\
\text { framework for understanding all of this. If the } \\
\text { number of communication API and IT API can be } \\
\text { minimized and set orthogonally to each other, you } \\
\text { could develop some significant insight. In much the } \\
\text { same way that REST allowed a better } \\
\text { understanding of the web, I think there's an } \\
\text { opportunity here to create a better understanding of }\end{array}$ \\
\hline
\end{tabular}




\begin{tabular}{|l|l|}
\hline & $\begin{array}{l}\text { utilizing the web. } \\
\text { You may ignore my rantings. I've enclosed your } \\
\text { questionnaire and if I can be of more help, just ask. } \\
\text { Accepted all API classifications as assigned } \\
\text { Sale Telephony -> Professional Relationship } \\
\text { Management } \\
\text { Payment enhanced messaging } \rightarrow \text { Payment } \\
\text { Messaging } \\
\text { Payment enhanced telephony } \rightarrow \text { Payment } \\
\text { Messaging }\end{array}$ \\
\hline $\begin{array}{l}\text { The only changes I'd make would be changing the } \\
\text { two API classifications (Chat and Messaging should } \\
\text { be "Both"). I'm good with the naming you've } \\
\text { allocated - in that regard you'll find more opinions } \\
\text { that people on how to name things, so I personally } \\
\text { never get hung up; as long as the taxonomy is } \\
\text { known. }\end{array}$ \\
\hline $\begin{array}{l}\text { Chat/calendar could either use telephony or there's } \\
\text { a telephony/calendar category. Use cases are } \\
\text { things like wake-up calls, scheduled conference } \\
\text { call. } \\
\text { As well as "personal chat" there's "sales chat" aka } \\
\text { "click for agent" } \\
\text { In general, I see two issues with the presentation } \\
1 \text { some mashups could use or be remashed to } \\
\text { include multiple and interchangeable } \\
\text { communications api - telephony, sms, email } \\
2 \text { some apis seem to overlap in that telephony } \\
\text { seems to cover both voice and sms, which is a bit } \\
\text { overbroad. }\end{array}$ \\
\hline
\end{tabular}

Table 9 - CEA expert comments 
In summary:

- Most experts indicated that all the mashups found were CEAs

- The mashup type names created by the researcher were only valuable as unique identifiers, and were not descriptive of the mashups that the mashup type contained

- The API categories provided on programmableweb were inconsistently interpretation by submitters

\subsubsection{Outcome of step 7: Update CEA mashup types}

Given no one category was added or removed by the majority of the experts (two experts wanted to remove the "Chat" and "Messaging" categories from communication classification, one wanted to remove "Telephony", and one wanted to add "Enterprise" and "Medical" to the communications classification). Therefore, Table 8 remains the final version of the CEA Mashup types

\subsection{Value of CEA Mashup Types}

\subsubsection{Outcome of step 8: Text analysis}

Table 11 provides the outcome of Step 8. The categories that appear in the header of Table 11 are the TOTAL values extracted from the Lasswell Dictionary 
(http:/lwww.wih.harvard.edu/ inquirer/lasswell.htm) and organised in Table 10. The cells of Table 11 shows the "the percent of words in the text having that tag" (http://uww.webuse.umd.edu:9090/), where the text used was the mashup type descriptions and tags. 


\begin{tabular}{|c|c|c|}
\hline Lasswell tag category & Meaning & Definition \\
\hline Pow & Power & $\begin{array}{l}\text { A special case of the } \\
\text { exercise of influence, it is } \\
\text { the process of affecting } \\
\text { policies of others with the } \\
\text { help of (actual or } \\
\text { threatened) severe } \\
\text { deprivations for non- } \\
\text { conformity with the policies } \\
\text { intended }\end{array}$ \\
\hline Rc & Rectitude & $\begin{array}{l}\text { Comprises the moral } \\
\text { values ... virtue, goodness, } \\
\text { righteousness, and so on }\end{array}$ \\
\hline Rsp & Respect & $\begin{array}{l}\text { The value of status, honor, } \\
\text { recognition, prestige }\end{array}$ \\
\hline Aff & Affection & $\begin{array}{l}\text { The values of love and } \\
\text { friendship }\end{array}$ \\
\hline$\overline{\text { Wit }}$ & Wealth & $\begin{array}{l}\text { Income [or] services of } \\
\text { goods and persons } \\
\text { accruing to the person in } \\
\text { any way whatever }\end{array}$ \\
\hline Wib & Well-being & $\begin{array}{l}\text { The health and safety of } \\
\text { the organism }\end{array}$ \\
\hline Enl & Enlightenment & $\begin{array}{l}\text { Knowledge, insight and } \\
\text { information concerning } \\
\text { personal and cultural } \\
\text { relations }\end{array}$ \\
\hline Skl & Skill & $\begin{array}{l}\text { Proficiency in any practice } \\
\text { whatever, whether in arts } \\
\text { or crafts, trade or } \\
\text { profession }\end{array}$ \\
\hline
\end{tabular}

Table 10 - General Inquirer Lasswell tag categories and definitions 


\begin{tabular}{|c|c|c|c|c|c|c|c|c|c|}
\hline \multirow[t]{3}{*}{ Mashup type } & \multirow{3}{*}{$\begin{array}{l}\text { Word } \\
\text { count }\end{array}$} & \multicolumn{8}{|c|}{ Lasswell Domains } \\
\hline & & \multicolumn{4}{|c|}{ Deference } & \multicolumn{4}{|c|}{ Welfare } \\
\hline & & Pow & Rc & Rsp & $\overline{\text { Aff }}$ & Wit & W/b & Enl & SkI \\
\hline $\begin{array}{l}\text { Messaging / } \\
\text { Bookmarks }\end{array}$ & 139 & $3.60 \%$ & $1.44 \%$ & $0.00 \%$ & $1.44 \%$ & $0.00 \%$ & $0.72 \%$ & $7.91 \%$ & $1.44 \%$ \\
\hline $\begin{array}{l}\text { Chat / } \\
\text { Calendar }\end{array}$ & 113 & $4.42 \%$ & $1.77 \%$ & $0.88 \%$ & $0.88 \%$ & $0.88 \%$ & $0.00 \%$ & $10.62 \%$ & $0.88 \%$ \\
\hline $\begin{array}{l}\text { Telephony / } \\
\text { Enterprise }\end{array}$ & 193 & $6.74 \%$ & $0.52 \%$ & $0.00 \%$ & $1.04 \%$ & $3.11 \%$ & $0.00 \%$ & $3.63 \%$ & $0.52 \%$ \\
\hline $\begin{array}{l}\text { Messaging / } \\
\text { Events }\end{array}$ & 197 & $2.03 \%$ & $0.00 \%$ & $0.00 \%$ & $0.51 \%$ & $0.00 \%$ & $0.00 \%$ & $6.09 \%$ & $0.00 \%$ \\
\hline $\begin{array}{l}\text { Messaging / } \\
\text { News }\end{array}$ & 75 & $4.00 \%$ & $0.00 \%$ & $0.00 \%$ & $1.33 \%$ & $0.00 \%$ & $1.33 \%$ & $12.00 \%$ & $0.00 \%$ \\
\hline Chat / Other & 143 & $6.29 \%$ & $2.10 \%$ & $0.00 \%$ & $0.70 \%$ & $2.10 \%$ & $3.50 \%$ & $8.39 \%$ & $2.10 \%$ \\
\hline $\begin{array}{l}\text { Messaging / } \\
\text { Other }\end{array}$ & 181 & $3.31 \%$ & $1.10 \%$ & $0.00 \%$ & $1.10 \%$ & $0.00 \%$ & $0.55 \%$ & $11.05 \%$ & $3.31 \%$ \\
\hline $\begin{array}{l}\text { Messaging / } \\
\text { Payment }\end{array}$ & 105 & $5.71 \%$ & $0.00 \%$ & $0.95 \%$ & $0.00 \%$ & $2.86 \%$ & $0.00 \%$ & $11.43 \%$ & $3.81 \%$ \\
\hline $\begin{array}{l}\text { Telephony I } \\
\text { Payment }\end{array}$ & 183 & $3.83 \%$ & $0.00 \%$ & $0.55 \%$ & $1.09 \%$ & $2.19 \%$ & $0.55 \%$ & $9.84 \%$ & $4.37 \%$ \\
\hline $\begin{array}{l}\text { Chat / } \\
\text { Photos } \\
\end{array}$ & 103 & $2.91 \%$ & $1.94 \%$ & $0.97 \%$ & $0.97 \%$ & $0.00 \%$ & $0.00 \%$ & $4.85 \%$ & $1.94 \%$ \\
\hline $\begin{array}{l}\text { Messaging / } \\
\text { Photos }\end{array}$ & 291 & $4.47 \%$ & $0.69 \%$ & $0.00 \%$ & $1.03 \%$ & $0.00 \%$ & $0.34 \%$ & $6.53 \%$ & $1.03 \%$ \\
\hline $\begin{array}{l}\text { Telephony / } \\
\text { Photos }\end{array}$ & 105 & $1.90 \%$ & $0.00 \%$ & $1.90 \%$ & $0.95 \%$ & $0.00 \%$ & $1.90 \%$ & $0.95 \%$ & $1.90 \%$ \\
\hline $\begin{array}{l}\text { Telephony I } \\
\text { Reference }\end{array}$ & 176 & $2.27 \%$ & $0.00 \%$ & $0.57 \%$ & $0.00 \%$ & $2.27 \%$ & $0.00 \%$ & $7.95 \%$ & $1.70 \%$ \\
\hline $\begin{array}{l}\text { Chat / } \\
\text { Search }\end{array}$ & 198 & $5.05 \%$ & $1.01 \%$ & $0.51 \%$ & $1.01 \%$ & $1.01 \%$ & $0.00 \%$ & $11.11 \%$ & $3.03 \%$ \\
\hline $\begin{array}{l}\text { Messaging / } \\
\text { Search }\end{array}$ & 453 & $1.32 \%$ & $0.66 \%$ & $0.22 \%$ & $0.66 \%$ & $2.65 \%$ & $0.66 \%$ & $7.95 \%$ & $1.55 \%$ \\
\hline $\begin{array}{l}\text { Telephony I } \\
\text { Search }\end{array}$ & 100 & $5.00 \%$ & $0.00 \%$ & $1.00 \%$ & $0.00 \%$ & $1.00 \%$ & $0.00 \%$ & $8.00 \%$ & $1.00 \%$ \\
\hline $\begin{array}{l}\text { Chat / } \\
\text { Shopping }\end{array}$ & 272 & $5.88 \%$ & $0.00 \%$ & $0.37 \%$ & $0.37 \%$ & $2.94 \%$ & $0.37 \%$ & $8.09 \%$ & $3.68 \%$ \\
\hline $\begin{array}{l}\text { Messaging / } \\
\text { Shopping }\end{array}$ & 349 & $2.29 \%$ & $0.00 \%$ & $0.29 \%$ & $0.29 \%$ & $4.30 \%$ & $0.86 \%$ & $9.17 \%$ & $4.58 \%$ \\
\hline Telephony I & 271 & $2.58 \%$ & $0.00 \%$ & $1.48 \%$ & $0.00 \%$ & $3.69 \%$ & $0.00 \%$ & $7.75 \%$ & $3.32 \%$ \\
\hline
\end{tabular}




\begin{tabular}{|c|c|c|c|c|c|c|c|c|c|}
\hline \multirow[t]{3}{*}{ Mashup type } & \multirow{3}{*}{$\begin{array}{l}\text { Word } \\
\text { count }\end{array}$} & \multicolumn{8}{|c|}{ Lasswell Domains } \\
\hline & & \multicolumn{4}{|c|}{ Deference } & \multicolumn{4}{|c|}{ Welfare } \\
\hline & & Pow & $\mathbf{R C}$ & Rsp & Aff & Wit & Wh & Enl & SkI \\
\hline \multicolumn{10}{|l|}{ Shopping } \\
\hline $\begin{array}{l}\text { Messaging / } \\
\text { Storage }\end{array}$ & 95 & $3.16 \%$ & $2.11 \%$ & $1.05 \%$ & $1.05 \%$ & $2.11 \%$ & $0.00 \%$ & $11.58 \%$ & $4.21 \%$ \\
\hline $\begin{array}{l}\text { Telephony / } \\
\text { Storage }\end{array}$ & 101 & $7.92 \%$ & $0.00 \%$ & $1.98 \%$ & $0.00 \%$ & $2.97 \%$ & $0.00 \%$ & $10.89 \%$ & $3.96 \%$ \\
\hline $\begin{array}{l}\text { Telephony I } \\
\text { Utility }\end{array}$ & 114 & $3.51 \%$ & $0.00 \%$ & $0.88 \%$ & $2.63 \%$ & $0.00 \%$ & $0.00 \%$ & $11.40 \%$ & $1.75 \%$ \\
\hline $\begin{array}{l}\text { Messaging / } \\
\text { Weather }\end{array}$ & 111 & $2.70 \%$ & $1.80 \%$ & $0.00 \%$ & $0.90 \%$ & $0.00 \%$ & $0.00 \%$ & $8.11 \%$ & $0.90 \%$ \\
\hline
\end{tabular}

Table 11 - CEA Mashup type value percentages

Table 12 is created by assigning percentage levels (High, Medium, or Low) to the percentage values in Table 12. A percentage of six percent or more is considered a high percentage, a medium percentage is any value between six and two percent, and a low percentage is any value below two percent. Results from Table 12 suggest that most CEA mashups are related to the acquisition of knowledge (20 out of 23 have high Enlightenment), some aspect of control (21 have medium to high Power) and do not address morality (21 have low Rectitude), respect (all 23 have low Respect), social (22 have low Affection) or health and safety (22 have low Well-being). 


\begin{tabular}{|c|c|c|c|c|c|c|c|c|c|}
\hline \multirow[t]{3}{*}{ Mashup type } & \multirow[t]{3}{*}{ Word count } & \multicolumn{8}{|c|}{ Lasswell Domains } \\
\hline & & \multicolumn{4}{|c|}{ Deference } & \multicolumn{4}{|c|}{ Welfare } \\
\hline & & Pow & $\mathbf{R c}$ & $\mathbf{R s p}$ & Aff & Wit & WIb & EnI & Skl \\
\hline Messaging/Bookmarks & 139 & $\mathbf{M}$ & $L$ & $\mathrm{~L}$ & $L$ & $\mathrm{~L}$ & $\mathrm{~L}$ & $\mathrm{H}$ & $\mathrm{L}$ \\
\hline Chat/Calendar & 113 & $\mathbf{M}$ & $\mathrm{L}$ & $\bar{L}$ & $\mathrm{~L}$ & $\mathbf{L}$ & $\bar{L}$ & $\mathrm{H}$ & $\mathrm{L}$ \\
\hline Telephony/Enterprise & 193 & $\bar{H}$ & $\mathrm{~L}$ & $\mathbf{L}$ & $\mathrm{L}$ & $M$ & $\bar{L}$ & $\bar{M}$ & $\mathrm{~L}$ \\
\hline Messaging/Events & 197 & $\bar{M}$ & $\mathrm{~L}$ & $\mathrm{~L}$ & $\mathrm{~L}$ & $\mathbf{L}$ & $\bar{L}$ & $\mathrm{H}$ & $\mathrm{L}$ \\
\hline Messaging/News & 75 & $M$ & $\mathrm{~L}$ & $\mathbf{L}$ & $\mathrm{L}$ & $\mathbf{L}$ & $\mathbf{L}$ & $\bar{H}$ & $\mathrm{~L}$ \\
\hline Chat/Other & 143 & $\mathrm{H}$ & $\bar{M}$ & $\bar{L}$ & $L$ & $\mathbf{M}$ & $\mathbf{M}$ & $\mathrm{H}$ & $\mathbf{M}$ \\
\hline Messaging/Other & 181 & $\bar{M}$ & $\mathrm{~L}$ & $\bar{L}$ & $\mathbf{L}$ & $\bar{L}$ & $\bar{L}$ & $\mathrm{H}$ & $\mathbf{M}$ \\
\hline Messaging/Payment & 105 & $\mathbf{M}$ & $\mathrm{L}$ & $\bar{L}$ & $\mathrm{~L}$ & $\mathbf{M}$ & $\mathbf{L}$ & $\mathrm{H}$ & $\mathbf{M}$ \\
\hline Telephony/Payment & 183 & $M$ & $\mathrm{~L}$ & $\mathbf{L}$ & $L$ & $M$ & $L$ & $\mathrm{H}$ & $M$ \\
\hline Chat/Photos & 103 & $\bar{M}$ & $\mathrm{~L}$ & $\bar{L}$ & $\mathrm{~L}$ &  & $\mathbf{L}$ & $\mathbf{M}$ & $\mathrm{L}$ \\
\hline Messaging/Photos & 291 & $\mathbf{M}$ & $\mathrm{L}$ & $\mathrm{L}$ & $\mathbf{L}$ & $L$ & $\bar{L}$ & $\mathrm{H}$ & $\mathrm{L}$ \\
\hline Telephony/Photos & 105 & $\mathbf{L}$ & $\mathrm{L}$ & $L$ & $\mathrm{~L}$ & $L$ & $L$ & $\mathbf{L}$ & $L$ \\
\hline Telephony/Reference & 176 & $\mathbf{M}$ & $\mathbf{L}$ & $L$ & $\mathrm{~L}$ & $M$ & $L$ & $\bar{H}$ & $\mathrm{~L}$ \\
\hline Chat/Search & 198 & $\bar{M}$ & $\mathrm{~L}$ & $\mathbf{L}$ & $\mathrm{L}$ & $\mathbf{L}$ & $L$ & $\mathrm{H}$ & $M$ \\
\hline Messaging/Search & 453 & $\mathbf{L}$ & $\mathrm{L}$ & $\underline{L}$ & $\mathrm{~L}$ & $M$ & $\mathbf{L}$ & $\mathrm{H}$ & $L$ \\
\hline Telephony/Search & 100 & $\mathbf{M}$ & $\mathrm{L}$ & $\bar{L}$ & $\mathrm{~L}$ & $\mathrm{~L}$ & $\mathbf{L}$ & $\mathrm{H}$ & $L$ \\
\hline Chat/Shopping & 272 & $\bar{M}$ & $\mathrm{~L}$ & $\mathrm{~L}$ & $\mathrm{~L}$ & $M$ & $L$ & $\mathrm{H}$ & $M$ \\
\hline Messaging/Shopping & 349 & $\bar{M}$ & $\mathrm{~L}$ & $L$ & $\mathrm{~L}$ & $M$ & $L$ & $H$ & $M$ \\
\hline Telephony/Shopping & 271 & $\bar{M}$ & $\mathrm{~L}$ & $\mathbf{L}$ & $\bar{L}$ & $M$ & $\mathbf{L}$ & $\mathrm{H}$ & $M$ \\
\hline Messaging/Storage & 95 & $M$ & $\mathbf{M}$ & $L$ & $\mathrm{~L}$ & $M$ & L & $\mathrm{H}$ & $M$ \\
\hline Telephony/Storage & 101 & $\mathrm{H}$ & $L$ & $\mathrm{~L}$ & $\mathrm{~L}$ & $M$ & $L$ & $\mathrm{H}$ & $M$ \\
\hline Telephony/Utility & 114 & $M$ & $\mathbf{L}$ & $L$ & $M$ & $\mathrm{~L}$ & $L$ & $\mathbf{H}$ & $L$ \\
\hline Messaging/Weather & 111 & $M$ & $\mathrm{~L}$ & $L$ & $\mathrm{~L}$ & $\mathrm{~L}$ & $\mathrm{~L}$ & $\mathbf{H}$ & $\mathrm{L}$ \\
\hline
\end{tabular}

Table 12 - CEA mashup type value ranges 


\subsection{Main findings}

The main findings of this research are that:

- Of the 53 API categories, only 14 are classified as being IT categories, and 3 are a communication categories

- There is no clear consensus among CEA experts (self identified), as to what constitutes a communication category, or how CEA mashups should be named.

- CEA experts agreed on the IT categories, and that based on their classifications of a communication category, that the mashups discovered were CEA mashups.

- This research resulted in 23 different mashup types, most having less than four mashups.

- Most CEA mashups are related to the acquisition of knowledge, and some aspect of control. 


\section{DISCUSSION OF RESULTS}

Chapter 5 is organized into three sections. Section 5.1 discusses the results from the CEA mashup type identification. Section 5.2 discusses the results of the text analysis of the mashup types to determine the values that these types provide. Section 5.3 links the findings of this research with the existing literature.

\subsection{CEA mashup types}

\subsubsection{The area of CEA mashups is wide and shallow}

During the initial results of the CEA mashups type identification (Table 7), it was found that:

- The majority of the potential CEA mashup types contain at least one mashup ( 62 total mashup types/114 potential mashup types $=54.39 \%$ )

- Most mashup types contain less than four mashups $(75.81 \%$, see Table 13 for a complete list)

- The distribution of the number of mashups is not a normal distribution (As can be seen in Table 13, 23 mashup types have only one mashup and the number of mashups per mashup type trends lower from that point on) 
Table 13 illustrates the last two points in table form. The second column of Table 13 is the number of mashup types that have the number of mashups indicated in the first column. The third column is the percentage of mashup types that have the corresponding number of mashups in the first column or less.

\begin{tabular}{|r|r|r|}
\hline $\begin{array}{r}\text { Number } \\
\text { of } \\
\text { mashups }\end{array}$ & $\begin{array}{r}\text { Number } \\
\text { of } \\
\text { mashup } \\
\text { types }\end{array}$ & $\begin{array}{r}\text { Total } \\
\text { Percentage } \\
\text { of mashup } \\
\text { types }\end{array}$ \\
\hline 1 & 23 & $37.10 \%$ \\
\hline 2 & 16 & $62.90 \%$ \\
\hline 3 & 8 & $75.81 \%$ \\
\hline 4 & 4 & $82.26 \%$ \\
\hline 5 & 3 & $87.10 \%$ \\
\hline 6 & 3 & $91.94 \%$ \\
\hline 7 & 0 & $91.94 \%$ \\
\hline 8 & 2 & $95.16 \%$ \\
\hline 9 & 0 & $95.16 \%$ \\
\hline 10 & 1 & $96.77 \%$ \\
\hline 11 & 1 & $98.39 \%$ \\
\hline 12 & 0 & $98.39 \%$ \\
\hline 13 & 0 & $98.39 \%$ \\
\hline 14 & 1 & $100.00 \%$ \\
\hline
\end{tabular}

Table 13 - CEA mashup types by number of mashups that they contain

\subsubsection{Communication is an enhancement, not a fundamental component}

One of the key feedbacks from the CEA experts was that, in many cases, based on the mashup descriptions alone it would be very difficult to identify the CEA mashups. For example, the "TeachStreet" mashup (http://www.programmableweb.com/mashup/teachstreet) appears in seven 
different CEA mashup types, containing both messaging (Twilio SMS) and telephony (Twilio) APIs, yet from the description:

TeachStreet helps lifelong learners find great classes and teachers, empowering teachers with robust online tools to manage their teaching businesses, and enabling schools to more effectively generate leads for their classes.

and tags:

classes, education, mapping, schools, social, teachers.

Communication features can not easily be inferred. Even a search of the actual website only makes a passing reference to "Toll-free Call Tracking" (http://www.teachstreet.com/subscription/pricing) and no references to "messaging" or "SMS" could be found. This is an indication that the mashup supplier does not believe that communication features provides high value to their customers. Similar results can be found from other mashups such as Pageflakes (http://www.programmableweb.com/mashup/pageflakes), Snippee (http://wuw.programmableweb.com/mashup/snippee), Bester News (http://www.programmableweb.com/mashup/bester-news), and Webjam (http://www.programmableweb.com/mashup/webjam). 


\subsubsection{Messaging is the most common communication API category}

According to Table 7, the CEA mashup types that have the most number of mashups $(14,11$, and 10) use Messaging APIs. It can also be seen from this same table that the total number of Messaging CEA mashups $(81,63$ if CEA mashup types with less than three mashups are ignored) are much greater than the number of Telephony CEA mashups $(51,35$ if CEA mashup types with less than three mashups are ignored) or Chat CEA mashups (47, 25 if CEA mashup types with less than three mashups are ignored). Finally, in Table 8, there are 10 Messaging CEA mashups types, as opposed to 8 Telephony CEA mashups types and 5 Chat CEA mashups types. All of this is a clear indication that Messaging is the most common communication API category to be used for CEA mashups.

One point that is interesting to note is that despite the fact that the Telephony category has a greater number of APIs than the Messaging category (134 as opposed to 91 ) and a greater number of mashups (238 as opposed to 215). 


\subsection{CEA mashup customer values}

\subsubsection{Opportunities exist in expressing CEA mashup customer values}

It should be noted that the area of CEA mashups is still relatively unexplored.

The stated values that the suppliers provide are still quite limited in scope, and lack any depth of analysis beyond stating the obvious.

A number of early attempts at this research to determine CEA value from a customer perspective were unsuccessful. The first approach was to determine a list of CEA supplier companies. The next approach was to determine the supplier's perspective of customer value from a text search of their websites, and then contact their customers to get their perspective and then compare and contrast the two perspectives. It was determined that the suppliers would not provide a list of their customers, making this approach was not viable. The second approach was to gather user comments from the testimonials on the suppliers' websites. This approach was also unsuccessful since most of the indentified CEA supplier websites did not have such a section and the ones that did only had comments such as "far better than any of the other trials/software packages I've tried" which provided no valuable data. The final attempt was to search CEA mashup websites and gather user feedback from the mashup comments. To gather information, a prototype of the computer program built for 
this research found that almost none of the mashups had any comments and therefore provided insufficient data to do such analysis.

These two exercises indicate opportunities for CEA mashup suppliers to engage their customers more. The suppliers could directly survey their customers to determine the few elements of the mashup that matter the most to each customer, or indirectly determine the elements by actively soliciting questions and comments. The suppliers could then document "the value of this superior performance, and communicating it in a way that conveys a sophisticated understanding of the customer's business priorities" (Anderson, Narus \& Van Rossum 2006).

\subsubsection{The Affection values of CEA mashups do not appear high in the list}

The results of Table 12 that surprised the researcher were that the Affection values were so low. Given the popularity of IT applications such as Facebook, Linkedln and Twitter indicating that social networking is a growing area, it is surprising that there aren't CEA mashups with social networking customer value. One explanation for the low Affection value is that the Social APIs were not explicitly added in the analysis (see Table 5), but mashups that used the Social APIs were not excluded. The suppliers did not put high value on the social aspects of their mashup and therefore did not emphasize it in the descriptions and tags (e.g., SmartTickr http://uww.programmableweb.com/mashup/smarttickr 
described as "SmartTickr.com is a realtime Ajax Reader for RSS-Feeds, Twitter, Flicker, MySpace, Facebook, del.icio.us, Linkedln, Ebay, YouTube, Jaiku and Last.fm." uses social APIs Facebook, Linkedln, MySpace, and Twitter. Suppliers did not indicate customer value in the description), or the General Inquirer tag list for Affection is insufficient for the language used in mashups (e.g., SocialOyster http://unw.programmableweb.com/mashup/socialoyster is described as "Create an Oysterpass". Your Oysterpass will show your social activities at the internet. Search on different applications. Follow your friends live at your Oysterline" and used social APIs Linkedln, MySpace, Tumblr, and Twitter, and tags "mapping", "messaging", "news", "photo", "social", "timeline". The only word from this description that appears in the Affection tag list is "friend").

\subsubsection{Different CEA mashup types can provide the same value type}

Given there are eight Lasswell tag categories, and Table 12 divides the percentage values into three percentage levels, there are a possibility of 6,561 $\left(3^{8}\right)$ different combinations or value types. Therefore, it is not unreasonable to assume that each of the twenty three CEA mashup types would have a unique corresponding value type, yet as indicated in Table 14, this is not true. Table 14 is created by grouping together mashup types from Table 12 that have the same percentage levels for all eight Lasswell tag categories. Results from Table 14 suggest that CEA mashups provide twelve different value types, most containing 
only one mashup type. There are three value types that contain more than one mashup type. Value type 7 contains all of the purchasing and shopping CEA mashups, regardless of the communication categories, and could be summarized as "provides greater knowledge (high enlightenment), and improved control (medium power), skill (medium skill) and money (medium wealth)". Value type 4 could be summarized as "provides greater knowledge (high enlightenment), and improved control (medium power)". Value type 5 could be summarized as "provides greater knowledge (high enlightenment), and improved control (medium power), and skill (medium skill) 


\begin{tabular}{|c|c|c|c|c|c|c|c|c|c|}
\hline \multirow{3}{*}{$\begin{array}{l}\text { Value } \\
\text { type }\end{array}$} & \multirow[t]{3}{*}{ Mashup types } & \multicolumn{8}{|c|}{ Lasswell Domains } \\
\hline & & \multicolumn{4}{|c|}{ Deference } & \multicolumn{4}{|c|}{ Welfare } \\
\hline & & Pow & $\mathbf{R C}$ & Rsp & Aff & W/t & W/b & Enl & Skl \\
\hline 1 & Telephony/Photos & $L$ & $\mathrm{~L}$ & $\mathrm{~L}$ & $L$ & $\mathbf{L}$ & $\mathbf{L}$ & $\mathbf{L}$ & $\mathrm{L}$ \\
\hline$\overline{2}$ & Messaging/Search & $\mathrm{L}$ & $\bar{L}$ & $\bar{L}$ & $\mathrm{~L}$ & $\bar{M}$ & $\bar{L}$ & $H$ & $\mathrm{~L}$ \\
\hline$\overline{3}$ & Chat/Photos & $\bar{M}$ & L & $\mathbf{L}$ & $\bar{L}$ & $\mathrm{~L}$ & $\bar{L}$ & $\bar{M}$ & $\mathrm{~L}$ \\
\hline & $\begin{array}{l}\text { Messaging/Bookmarks } \\
\text { Chat/Calendar } \\
\text { Messaging/Events } \\
\text { Messaging/News } \\
\text { Messaging/Photos } \\
\text { Telephony/Search } \\
\text { Messaging/Weather }\end{array}$ & $\bar{M}$ & $\bar{L}$ & $\bar{L}$ & $\bar{L}$ & $\bar{L}$ & $\bar{L}$ & $H$ & $L$ \\
\hline & $\begin{array}{l}\text { Messaging/Other } \\
\text { Chat/Search }\end{array}$ & $\bar{M}$ & $\mathrm{~L}$ & $\mathrm{~L}$ & $L$ & $\bar{L}$ & $\bar{L}$ & $\mathrm{H}$ & $\bar{M}$ \\
\hline 6 & Telephony/Reference & $M$ & $L$ & $\mathbf{L}$ & L & $\mathbf{M}$ & $\mathbf{L}$ & $\mathrm{H}$ & $L$ \\
\hline & $\begin{array}{l}\text { Messaging/Payment } \\
\text { Telephony/Payment } \\
\text { Chat/Shopping } \\
\text { Messaging/Shopping } \\
\text { Telephony/Shopping }\end{array}$ & $\bar{M}$ & $\bar{L}$ & $\bar{L}$ & $\bar{L}$ & $\bar{M}$ & $\mathrm{~L}$ & $\mathrm{H}$ & $\bar{M}$ \\
\hline 8 & Telephony/Utility & $\bar{M}$ & L & $L$ & $M$ & $\mathbf{L}$ & $\mathbf{L}$ & $\mathrm{H}$ & $\mathbf{L}$ \\
\hline$\overline{9}$ & Messaging/Storage & $\bar{M}$ & $\bar{M}$ & $L$ & $\bar{L}$ & $\bar{M}$ & $\mathrm{~L}$ & $\mathrm{H}$ & $\mathbf{M}$ \\
\hline 10 & Telephony/Enterprise & $\mathrm{H}$ & $L$ & $L$ & $\mathrm{~L}$ & $M$ & $L$ & $M$ & $L$ \\
\hline 11 & Telephony/Storage & $\mathrm{H}$ & $\mathrm{L}$ & $\mathrm{L}$ & $\mathrm{L}$ & $\bar{M}$ & $\mathbf{L}$ & $\mathrm{H}$ & $\mathbf{M}$ \\
\hline 12 & Chat/Other & $\mathrm{H}$ & $\bar{M}$ & $L$ & $\mathbf{L}$ & $\mathbf{M}$ & $\mathbf{M}$ & $\mathrm{H}$ & $M$ \\
\hline
\end{tabular}

Table 14 - CEA mashup value types

The eight Lasswell tag categories are generalized into two domains (i.e.,

Deference and Welfare). Table 15 shows the sum of each domain percentages

from Table 11. 


\begin{tabular}{|l|r|r|r|}
\hline & \multirow{2}{*}{$\begin{array}{c}\text { Word } \\
\text { Mashup type }\end{array}$} & \multicolumn{2}{|c|}{ Lasswoll Domains } \\
\cline { 3 - 4 } & 139 & Deference & Welfare \\
\hline Messaging/Bookmarks & 113 & $7.96 \%$ & $10.07 \%$ \\
\hline Chat/Calendar & 193 & $8.29 \%$ & $7.39 \%$ \\
\hline Telephony/Enterprise & 197 & $2.54 \%$ & $6.09 \%$ \\
\hline Messaging/Events & 75 & $5.33 \%$ & $13.33 \%$ \\
\hline Messaging/News & 143 & $9.09 \%$ & $16.08 \%$ \\
\hline Chat/Other & 181 & $5.52 \%$ & $14.92 \%$ \\
\hline Messaging/Other & 105 & $6.67 \%$ & $18.10 \%$ \\
\hline Messaging/Payment & 183 & $5.46 \%$ & $16.94 \%$ \\
\hline Telephony/Payment & 103 & $6.80 \%$ & $6.80 \%$ \\
\hline Chat/Photos & 291 & $6.19 \%$ & $7.90 \%$ \\
\hline Messaging/Photos & 105 & $4.76 \%$ & $4.76 \%$ \\
\hline Telephony/Photos & 176 & $2.84 \%$ & $11.93 \%$ \\
\hline Telephony/Reference & 198 & $7.58 \%$ & $15.15 \%$ \\
\hline Chat/Search & 453 & $2.87 \%$ & $12.80 \%$ \\
\hline Messaging/Search & 100 & $6.00 \%$ & $10.00 \%$ \\
\hline Telephony/Search & 272 & $6.62 \%$ & $15.07 \%$ \\
\hline Chat/Shopping & 349 & $2.87 \%$ & $18.91 \%$ \\
\hline Messaging/Shopping & 271 & $4.06 \%$ & $14.76 \%$ \\
\hline Telephony/Shopping & 95 & $7.37 \%$ & $17.89 \%$ \\
\hline Messaging/Storage & 101 & $9.90 \%$ & $17.82 \%$ \\
\hline Telephony/Storage & 114 & $7.02 \%$ & $13.16 \%$ \\
\hline Telephony/Utility & 111 & $5.41 \%$ & $9.01 \%$ \\
\hline MessagingMeather & & & \\
\hline
\end{tabular}

\section{Table 15 - CEA Mashup type domain value percentages}

Figure 2 shows a graph of the CEA mashup types of Lasswell domains from

Table 15, along with the average and median of these domain values. The graph in Figure 2 shows that mashup types tend to be centered near the top left corner of the graph, a relatively high Welfare compared to a relatively low Deference. This graph indicates that CEA mashup types are more about "stored worth, a 
'stock' or ability of some type" than "one accepting the cues or instructions of another" (Chadwick 1999).



Figure 2 - CEA Mashup type domain graph 
Figure 3 and Figure 4 use the data from Table 15, grouped by communication and IT API categories respectively. These graphs indicate no obvious relationship between API categories and Lasswell domain values. 


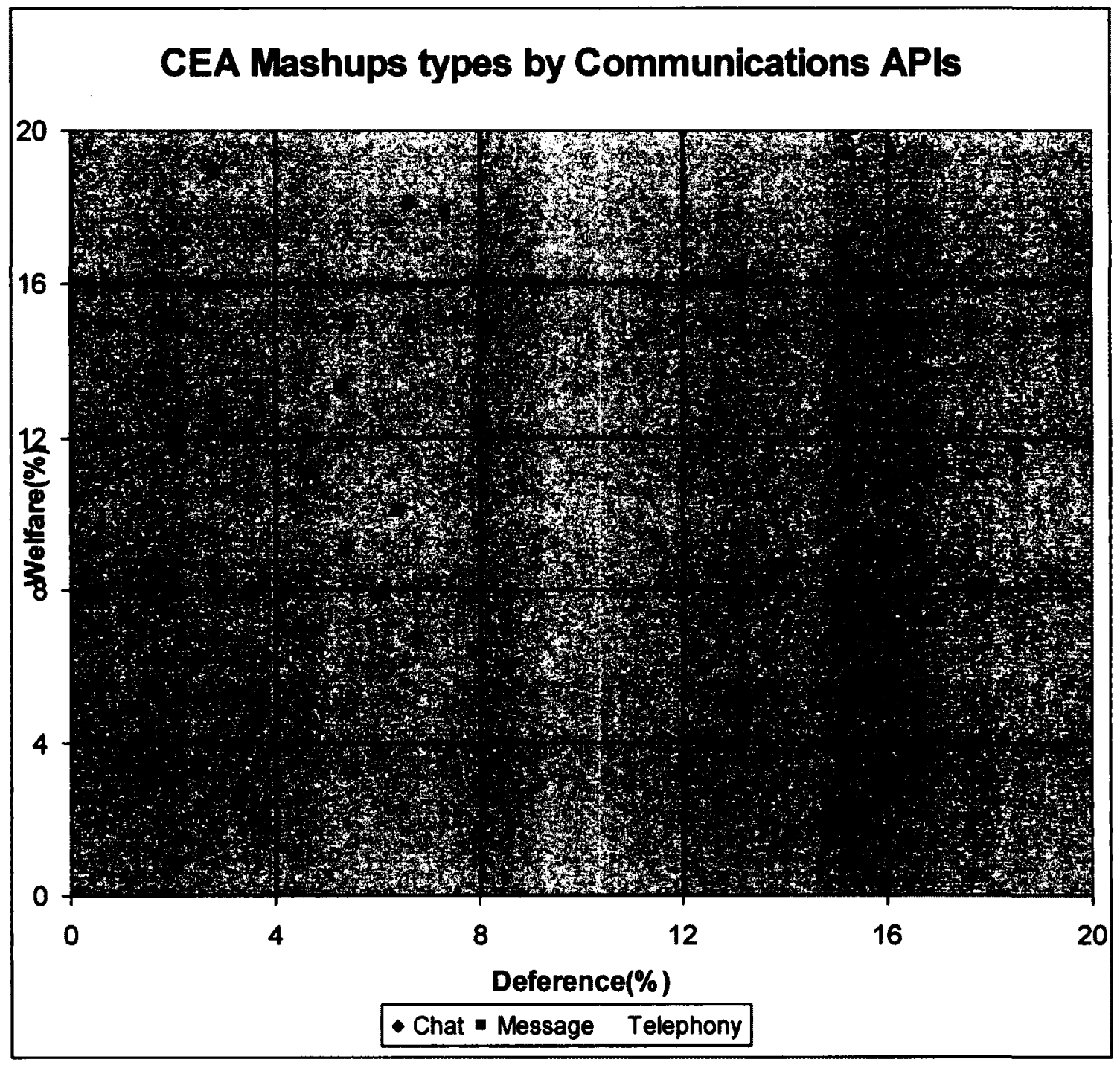

Figure 3 - CEA Mashup types by Communication APls graph 


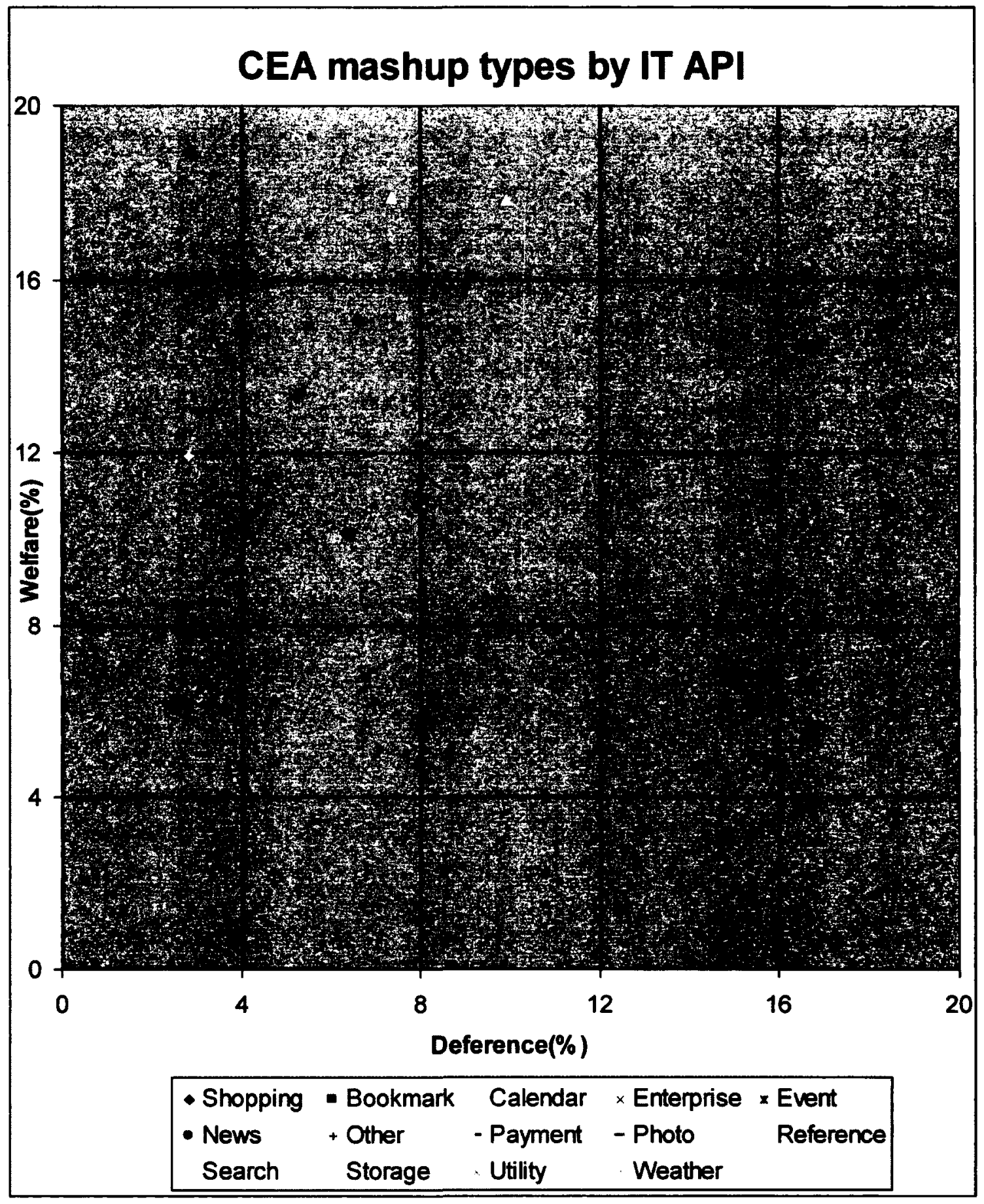

Figure 4 - CEA Mashup types by IT APIs graph 


\subsection{Linkage between research findings and literature review}

\subsubsection{CEAs are in the stage of ferment}

When a new technology is created, it is "crude and experimental" while companies attempt to absorb or destroy the new innovation. This experimental period, era of ferment, creates two related competitions: competition between the existing and the new technologies, and competition within the new technology. These competitions end with the emergence of the dominant design (Anderson \& Tushman 1990).

As indicated in section 5.1.1, there is a great deal of experimentation in the area of CEA mashups. This results in many different mashup types. The mashup types are also "crudely" defined and therefore it can be argued that CEA mashups are in the ferment stage.

Based on the literature, there should be an emergence of a CEA dominant design (Anderson \& Tushman 1990). If the dominant design does emerge, this will be a strong and significant indication of the survival of CEAs (Suarez \& Utterback 1995), and the sales of CEAs should increase (Anderson \& Tushman 1990). 


\subsubsection{Communication is augmentation to IT products}

Section 5.1.2 "Communication is an enhancement, not a fundamental component" indicates that current CEA mashups are primarily IT applications that have a communication component. This can be viewed as: most CEA mashups are a convergence of IT technology with communication technology.

Hacklin, Marxt and Fahrni (2010) observed that convergence evolves through distinct stages: knowledge convergence, technological convergence, application convergence, and industrial convergence. Knowledge convergence is the convergence of previously separate knowledge bases, thus combining information from different industries. Technological convergence is the evolution of knowledge convergence to create technological innovations that combines previously separate technologies. Applicational convergence is the evolution of technological convergence to create applications that have value greater than the sum of the original parts. Industrial convergence is the evolution of applicational convergence to create competitors from previously different industries.

Given that the technology to create CEA mashups exists, and the value of CEA mashups are still being developed (as seen in section 5.2.1 of this document), it is most likely that CEA mashups are in the later part of the technology 
convergence or early part of applicational convergence. CEA mashup developers should focus on creating opportunities for new value creation.

The addition of communication components to IT applications can also be viewed as creating an "augmented product" (Kotler 2007, Levitt 1980), since it adds functionality that exceeds those that are found in the "expected product".

This supports the last lesson learned, that in the case of CEA mashups, technology convergence creates an augmented product

\subsubsection{Voice is not the major communication feature}

The professional literature mostly describes CEA examples where the communication component is the integration of telephony. However, it was found that "CEAs Messaging is the most common communication API category" (See section 5.1.3).

One explanation for the difference between the telephony emphasis in the professional literature, and the observation that messaging is used more often in CEA mashups than telephony, is that most of the professional literature was written by Nortel (Becchina, Ciccarelli, Giotis \& Kenny 2007; Carbone \& Romagnino 2007; Carbone 2008; Oberg 2009; Roese 2007). Nortel, one of the leads in the development of CEAs, was a multinational telecommunications 
equipment manufacturer and the more CEAs that integrated telephony features, the greater value CEAs had to Nortel. For example in the Becchina, Ciccarelli, Giotis \& Kenny (2007) article, there is a preference for telephony technology. The words "message" and "unified messaging" each appeared five times, while the word "voice" appears 20 times, and "click-to-call" and "call-routing" (very specific applications of telephony technology) each appear three times.

Another possible reason that messaging is more common that telephony is that messaging is less complicated for the average developer to understand and create. For example, an event reminder application could send an SMS message, or a voice message. The SMS requires creating a text message and then sends the message to a phone number. The voice message system might require the ability to, store the best times to call, allow the receivers to respond using a touch-tone keypad and deal with alternate cases such as a busy signal, no answer, an answering machine ... (Piette 1997). 


\section{CONCLUSIONS, LIMITATION, AND FUTURE RESEARCH}

This chapter is organized into three sections. The first section provides the conclusions of this research. The second section provides the limitations of this research. The third section provides opportunities for future research.

\subsection{Conclusions}

Given that the number of CEAs is expected to grow, a better understanding of the types of CEAs that can and do exist is needed. Three key conclusions are provided. First, while many CEA mashup types exists only a very few number of mashups exist per type. Either CEA mashups are a much larger area than originally thought and the number of mashups per type will increase over time, or a select few CEA mashup types will emerge as the key types.

The second conclusion is that adding communication to information technology applications is an enhancement as opposed to providing fundamental value. If a company can create applications that have communication components that are fundamental to the product they can create niche markets. For example, Table 7 illustrates that there are no CEA mashups that combine medical APIs and any of the three communications API categories. In addition, Table 12 indicates that no CEA mashup type provides a high value for Well-being (health and safety). The 
highest percentage is $3.5 \%$ and most are less than $1 \%$. A company that could create a medical CEA mashup would be able to create a new market.

The third conclusion is that using the analysis and techniques presented in this paper, an individual or company could help the CEA mashup suppliers to find their competitors (i.e., other mashups having the same CEA mashup type as seen in Table 8, or value type from Table 14), find adjacent market segments (i.e., value types that differ by the percentage level of only one Lasswell category. For example, value types 6 and 7 in Table 14 only differ on the percentage level for the Skill category) and strengthen the description of their customer value proposition (i.e., compare value type detected by the use of Lasswell category tags to the supplier's intended customer value).

Some of the questions that are suggested from this research are:

- Is there a relationship between a CEA mashup type and APIs used in that CEA mashup type?

- What are the relationships between the different CEA mashup value types?

- What Lasswell values (or combinations) matter the most to CEA customers? 
- What are the values of the CEA mashup types using a different dictionary than Lasswell?

- What are the commercialization potentials of the twelve CEA value types identified?

\subsection{Limitation}

This research has at least four limitations:

1. The initial classification of categories into IT, Communication, Both, or Neither was done by TIM students and alumni. Given that all of these individuals were introduced to the concept of Communications Enabled Applications through the same graduate program, this may creates a unique perspective that may not be shared by those outside the program.

2. For simplification of effort, it was decided to select APIs based on ProgrammableWeb categories. This resulted in APIs that would be considered either an IT or Communication API to be excluded if they were in a "Both" category, causing mashups that could be considered CEA mashups to be missed. (e.g., Google Maps can be considered an IT API 
but since it belongs to the Mapping category, one of the Both categories, it was not considered)

3. The category of an API in the ProgrammableWeb is assigned by the submitter. The ProgrammableWeb does not provide definitions of or enforce uniform usage of categories. This creates at least two limitations 1) Placing an IT or Communication API in a Both category results in it not be considered in this research 2) if an IT API is placed in an otherwise Communications category or vice versa, the entire category would be considered a Both category and invalidate all APIs in the category from consideration in this research.

4. The mashup description and tags are assigned by the submitter. Incomplete or incorrect values would result in an invalid CEA mashup type name and the inability to determine the customer value of the mashup. This limitation is similar to the limitation described in section 3. 


\subsection{Future research}

This research identifies five opportunities for future research:

1. Automate the classification of categories based on a keyword search of the containing API descriptions and tags, and then repeat this research based on the new category classifications.

2. Redo this research but instead of classifying APIs based on the category that they belong to, create an automated process that classifies APIs based on keywords that appear in its description or tags

3. Use other attributes to classify APIs (e.g., all Amazon APIs can be considered as IT)

4. Use the "CEA mashup values" found in this research to search mashup description, tags or website for other CEA mashups this would eliminate the need to consider classifications, categories, or APIs.

5. Rerun the searches done in this research to track the changes to the number and types of CEA mashups 


\section{REFERENCES}

Abiteboul, S., Greenshpan, O. \& Milo, T. 2008. Modeling the mashup space. WIDM '08 Proceeding of the 10th ACM workshop on Web information and data management :87-94.

Adner, R. \& Levinthal, D.A. 2002. The Emergence of Emerging Technologies. California Management Review 45(1) :50-66.

Allemang, D. 2006. Rule-based intelligence in the Semantic Web-or-l'll settle for a web that's just not so dumb!. Rules and Rule Markup Languages for the Semantic Web, Second International Conference on :83-88.

Anderson, P. \& Tushman, M.L. 1990. Technological Discontinuities and Dominant Designs: A Cyclical Model of Technological Change. Administrative Science Quarterly 35(4) :604-633.

Anderson, J. C., Narus, J.A. \& Van Rossum, W. 2006. Customer Value Propositions in Business Markets. Harvard Business Review 84(3) :90-99.

Bailetti, T. 2009. How Open Source Strengthens Business Models. Open Source Business Resource http://osbr.ca/ojs/index.php/osbr/article/view/825/798 February. 
Balasubramaniam, S., Lewis, G., Simanta, S. \& Smith, D. 2008. Situated Software: Concepts, Motivation, Technology, and the Future. IEEE Software 25(6) :50-55.

Banerjee, N. \& Dasgupta, K. 2008. Telecom mashups: enabling web 2.0 for telecom services. ICUIMC '08 Proceedings of the 2nd international conference on Ubiquitous information management and communication :146-150.

Bardawil, M. 2011. Key Player Identification in the Mashup Ecosystem. Open Source Business Resource http://uww.osbr.ca/ojs/index.php/osbr/article/view/1268/1215 February.

Baresi, L., Heckel, R., Thone, S. \& Varro, D. 2006. Style based modeling and refinement of service oriented architectures. Software and System Modeling $5(2): 187-207$

Barth, A., Jackson, C. \& Mitchell, J. 2009. Securing Frame Communication in Browsers. Communications of the ACM 52(6) :83-91.

Becchina, W., Ciccarelli, L., Giotis, C. \& Kenny, J. 2007. Reinventing the enterprise with communications-enabled applications. Nortel Technical Journal $5: 33-44$. 
Beemer, B. \& Gregg, D. 2009. Mashups: A Literature Review and Classification Framework. Future Internet 1 :59-87.

Benjamins, V.R. 2008. Near-Term Prospects for Semantic Technologies. Intelligent Systems, IEEE 23(1) :76-88.

Benslimane, D., Dustdar, S. \& Sheth, A. 2008. Services Mashups: The New Generation of Web Applications. Internet Computing, IEEE 12(5) :13-15.

Boehm, B. \& Bhuta, J. 2008. Balancing Opportunities and Risks in ComponentBased Software Development. IEEE Software 25(6) :56-63.

Braga, D., Ceri, S., Daniel, F. \& Martinenghi, D. 2008. Mashing Up Search Services. Internet Computing, IEEE 12(5) :16-23.

Callahan, J. \& Lasry, E. 2004. The importance of customer input in the development of very new products. R\&D Management 34(2):107-120.

Cappiello, C., Daniel, F., Matera, M. \& Pautasso, C. 2010. Information Quality in Mashups. Internet Computing, IEEE 14(4) :14-22.

Carbone, P. \& Romagnino, S. 2007. Extreme value from next-generation applications and services. Nortel Technical Journal 5 :1-19. 
Carbone, P. 2008. Communications Enabled Applications - An Evolution to the Next Value Plane?. OASIS Symposium - Open Standards 2008 http://events.oasis-open.org/home/sites/events.oasisopen.org.home/files/Oasis\%2008\%20Nortel\%20PCarbone\%201.0.ppt\#561,2,Co mmunications April.

Chadwick, R.W. 1999. Lasswell's Value Theory Resconstructed as Means. http://www.hawaii.edu/int/rel/pols315/Text/Theory/lasswell.htm

Chen, Y., Carrillo, J.E., Vakharia A.J. \& Sin, P. 2010. Fusion Product Planning: A Market Offering Perspective. Decision Sciences 41(2) :325-353.

Chiticariu, L., Li, Y., Raghavan, S. \& Reiss, F. 2010. Enterprise information extraction: recent developments and open challenges. SIGMOD '10 Proceedings of the 2010 international conference on Management of data :1257-1258.

Chong, S., Liu, J., Myers, A., Qi, X., Vikram, K., Zheng, L. \& Zheng, X. 2009. Building Secure Web Applications with Automatic Partitioning. Communications of the ACM 52(2):79-87.

Chou, S. \& Lin, Y. 2000. Computer Telephony Integration and Its Applications. Communications Surveys \& Tutorials, IEEE 3(1) :2-11. 
Christensen, C.M. \& Rosenbloom, R.S. 1995. Explaining the attacker's advantage: Technological paradigms, organizational dynamics, and the value network. Research Policy 24(2) :233-257.

Crane, A. 2001. Unpacking the Ethical Product. Journal of Business Ethics $30(4): 361-373$.

Crites, S., Hsu, F. \& Chen, H. 2008. OMash: enabling secure web mashups via object abstractions. CCS '08 Proceedings of the 15th ACM conference on Computer and communications security :99-108.

Di Fabbrizio, G., Okken, T. \& Wilpon, J. 2009. A speech mashup framework for multimodal mobile services. ICMI-MLMI '09 Proceedings of the 2009 international conference on Multimodal interfaces :71-78.

Elmisery, A. \& Botvich, D. 2011. Agent based Middleware for Private Data Mashup in IPTV Recommender Services. Computer Aided Modeling and Design of Communication Links and Networks (CAMAD), 2011 IEEE 16th International Workshop on :107-111.

Gamble, T. \& Gamble, R. 2008. Monoliths to Mashups: Increasing Opportunistic Assets. IEEE Software 25(6):71-79. 
Geroski, P.A. 2000. Models of Technology Diffusion. Research Policy 29(4/5) :603-625.

Goyal, A. 2006. Consumer Perception Towards The Purchase of Credit Cards. Journal of Services Research $6: 179-190$.

Hacklin, F., Marxt, C. \& Fahrni, F. 2010. An evolutionary perspective on convergence: inducing a stage model of inter-industry innovation. International Journal of Technology Management 49(1/2/3) :220-249.

Haw, C. 2009. Goodbye Silicon Valley North, hello creative economy. Ottawa Business Journal 15(7) :14-14.

Hey, T. 2010. The Next Scientific Revolution. Harvard Business Review 88(11) :56-63.

Horrocks, I. 2008. Ontologies and the Semantic Web. Communications of the ACM 51(12) :58-67.

Hoyer, V. \& Fischer, M. 2008. Market Overview of Enterprise Mashup Tools. ICSOC '08 Proceedings of the 6th International Conference on ServiceOriented Computing :708-721. 
Hwang, J., Altmann, J. \& Kim, K. 2009. The structural evolution of the Web 2.0 service network. Online Information Review 33(6) :1040-1057.

Kanaparti, S. 2008. A Distributed-SOA Model for Unified Communication Services. ICWS '08 Proceedings of the 2008 IEEE International Conference on Web Services :529-536.

Keukelaere, F.D., Bhola, S., Steiner, M., Chari, S. \& Yoshihama S. 2008. SMash: Secure component model for cross-domain mashups on unmodified browsers. WWW '08 Proceeding of the 17th international conference on World Wide Web :535-544.

Kodama, F. 1992. Technology Fusion and The New R\&D. Harvard Business Review 70(4) :70-78.

Kodama, F. 1993. The Fusion Game. Harvard International Review 15(4) :1620.

Kocan, K.H. \& Robinson, D.C. 2011. Application enablement: A path to new opportunities for future services. Bell Labs Technical Journal 16(2) :1-4.

Kotler, P. 2004. Wrestling with Ethics. Marketing Management 13(6) :30-35. 
Kotler, P. 2006. Alphabet Soup. Marketing Management 15(2) :51-51.

Kotler, P. 2007. Marketing Management. Bloomsbury Business Library Management Library :58-58.

Leong, K.B. 2009. UC-enabled collaboration yields savings amid tough times. Network World Asia June/July :4-8.

Levitt, T. 1980. Marketing success through differentiation--of anything. Harvard Business Review 58(1) :83-91.

Levitt, T. 1990. The Case of the Mitigating Markets. Harvard Business Review $68(4): 12-24$.

Liu, Y., Liang, X., Xu, L., Staples, M. \& Zhu, L. 2011. Composing enterprise mashup components and services using architecture integration patterns. Journal of Systems \& Software 84(9):1436-1446.

Lorenzo, G., Hacid, H., Paik, H. \& Benatallah, B. 2009. Data integration in mashups. SIGMOD ACM Special Interest Group on Management of Data 34(1) :59-66. 
Magazinius, J., Askarov, A. \& Sabelfeld, A. 2010. A lattice-based approach to mashup security. ASIACCS '10 Proceedings of the 5th ACM Symposium on Information, Computer and Communications Security :15-23.

Maximilien, E.M. Ranabahu, A. \& Gomadam, K. 2008. An Online Platform for Web APIs and Service Mashups. Internet Computing, IEEE 12(5) :32-43.

Murphy, S. and Samir, W. 2009. 'In the cloud' IT creates new opportunities for network service providers. Journal of Telecommunications Management 2(2) $: 107-120$.

Murthy, S., Maier D. \& Delcambre, L. 2006. Mash-o-matic. DocEng '06 Proceedings of the 2006 ACM symposium on Document engineering :205214.

Oberg, H. 2009. The New Convergence Formula. Certification magazine 11(1) $: 22-25$.

Obrenovi, Ž., Gaševi, D. \& Eliëns, A. 2008. Stimulating Creativity through Opportunistic Software Development. IEEE Software 25(6) :64-70. 
Piette, J.D. 1997. Moving Diabetes Management From Clinic to Community: Development of a Prototype Based on Automated Voice Messaging. The Diabetes Educator 23(6):672-680.

Rake, J., Holschke, O., Offermann, P. \& Bub, U. 2009. Communication-enabled business processes as a service. 13th International Conference on Intelligence in Next Generation Networks.,ICIN 2009 :1-5.

Roese, J. 2007. Our vision for the future. The Future Made Simple May :1-5.

Rogers, E. 1995. Diffusion of innovations, Fourth Edition. New York: Free Press.

Rosch, E. 1999. Principles of categorization. In E. Margolis \& S. Laurence (Eds.), Concepts: Core readings :189-206. Cambridge, MA: MIT Press.

Rosenberg, F. Curbera, F. Duftler, M.J. \& Khalaf, R. 2008. Composing RESTful Services and Collaborative Workflows: A Lightweight Approach. Internet Computing, IEEE 12(5) :24-31.

Rosenberg, N. 1963. Technological Change in the Machine Tool Industry, 18401910. The Joumal of Economic History 23(4) :414-443. 
Rybczynski, T. \& Shetty, M. 2005. Unified Communications: Where The World Is Heading. Financial Executive 21(5) :31-33.

Sheth, A. \& Perry, M. 2008. Traveling the Semantic Web through Space, Time, and Theme. Internet Computing, IEEE 12(2):81-86.

Shiga, A. 2011. Competition in the Mashup Ecosystem. Open Source Business Resource http://unw.osbr.ca/ojs/index.php/osbr/article/view/1269/1216 February.

Sinnett, W.M. 2010. GREEN IT Is More Than A 'FEEL GOOD' Issue. Financial Executive 26(2) :60-63.

Spencer, B. \& Liu, S. 2008. Modelling the Sharing of Resources across Collaborative Sessions. Asia-Pacific Services Computing Conference, 2008. APSCC '08. IEEE :813-818.

Suarez, F.F. \& Utterback, J.M. 1995. Dominant Designs and the Survival of Firms. Strategic Management Journal 16(6) :415-430.

Toomim, M., Drucker, S., Dontcheva, M., Rahimi, A., Thomson, B. \& Landay, J. 2009. Attaching UI enhancements to websites with end users. $\mathrm{CHI}$ '09 
Proceedings of the 27th international conference on Human factors in computing systems :1859-1868.

Tuchinda, R., Szekely, P. \& Knoblock, C. 2008. Building Mashups by example. IUI '08 Proceedings of the 13th international conference on Intelligent user interfaces :139-148.

Utterback, J.M. \& Acee, H.J. 2005. Disruptive Technologies: An Expanded View. International Journal of Innovation Management 9(1):1-17.

Venkatachalam, L., Dhara, K.K., Krishnaswamy, V. \& Vernick, M. 2008.

Communication enabled web applications: the evolution of computer telephony integration. Proceedings of the third international conference on communications, IEEE COMSWARE 2008 June :275-278.

von Hippel, E. 1986. Lead Users: A Source of Novel Product Concepts. Management Science 32(7) :791-805.

von Hippel, E. 1998. Economics of product development by users: The impact of 'sticky' local information. Management Science 44(5) :629-644.

Wang, H. J., Fan, X., Howell, J. \& Jackson, C. 2007. Protection and communication abstractions for web browsers in MashupOS. SOSP '07 
Proceedings of twenty-first ACM SIGOPS symposium on Operating systems principles :1-16.

Warner, J. \& Chun, S. 2009. Privacy protection in government mashups. Information Polity: The International Journal of Government \& Democracy in the Information Age 14(1/2):75-90.

Weiss, M. \& Gangadharan, G.R. 2010. Modeling the mashup ecosystem: structure and growth. R\&D Management 40(1) :40-49.

Wu, R.W.S. \& Leung, G.L.K. 2008. Competition regulation in the Hong Kong telecommunications sector-Challenges and reforms. Telecommunications Policy 32(9-10):652-661.

Yu, J., Benatallah, B., Casati, F. \& Daniel, F. 2008. Understanding Mashup Development. Internet Computing, IEEE 12(5) :44-52.

Yu, S. \& Woodard, C.J. 2009. Innovation in the Programmable Web:

Characterizing the Mashup Ecosystem. Service-Oriented Computing -- ICSOC 2008 Workshops :136-147. 
Zarandioon, S., Yao, D. \& Ganapathy, V. 2008. OMOS: A Framework for Secure Communication in Mashup Applications. 2008 Annual Computer Security Applications Conference :355-364.

Zhang, L. 2009. The Use of Semantic Technologies in China. masters thesis, National University Of Ireland, Galway.

Zhang, L., Zhu, Q., Wang, W. \& Zhang, P. 2008. Web 2.0 and Semantic Web Based Intelligent Service System for Tourism Wireless Communications. Networking and Mobile Computing, 2008. WiCOM '08. 4th International Conference on : $1-4$.

Zou, J. \& Pavlovski, C. 2007. Towards Accountable Enterprise Mashup Services. IEEE International Conference on e-Business Engineering (ICEBE'07) :205212. 